\title{
Neuroscience in Nazi Europe Part III: Victims of the Third Reich
}

\author{
Lawrence A. Zeidman, Daniel Kondziella
}

\begin{abstract}
In Part I, neuroscience collaborators with the Nazis were discussed, and in Part II, neuroscience resistors were discussed. In Part III, we discuss the tragedy regarding European neuroscientists who became victims of the Nazi onslaught on "Non-Aryan" doctors. Some of these unfortunate neuroscientists survived Nazi concentration camps, but most were murdered. We discuss the circumstances and environment which stripped these neuroscientists of their profession, then of their personal rights and freedom, and then of their lives. We include a background analysis of anti-Semitism and Nazism in their various countries, then discuss in depth seven exemplary neuroscientist Holocaust victims; including Germans Ludwig Pick, Arthur Simons, and Raphael Weichbrodt, Austrians Alexander Spitzer and Viktor Frankl, and Poles Lucja Frey and Wladyslaw Sterling. By recognizing and remembering these victims of neuroscience, we pay homage and do not allow humanity to forget, lest this dark period in history ever repeat itself.
\end{abstract}

\begin{abstract}
RÉSUMÉ: La neuroscience en europe sous domination nazie, 3e partie : victimes du 3e reich. Dans la permière partie, nous avons traité de ceux qui ont collaboré avec les nazis dans le domaine des neurosciences et dans la deuxième partie, de ceux qui ont résisté. Dans cette troisième partie, nous traitons de la tragédie vécue par les neuroscientifiques européens qui ont été victimes de l'assaut des nazis contre les médecins «non-aryens ». Bien que la plupart furent assassinés, certains de ces infortunés neuroscientifiques ont survécu aux camps de concentration nazis. Nous discutons des circonstances et de l'environnement dans lesquels ces neuroscientifiques ont été dépouillés de leur profession, puis de leurs droits personnels et de leur liberté et finalement de leur vie. Nous incluons une analyse du contexte de l'antisémitisme et du nazisme dans différents pays, puis nous discutons en profondeur de sept neuroscientifiques exemplaires, victimes de l'holocauste, dont les allemands Ludwig Pick, Arthur Simons et Raphaël Weichbrodt, les autrichiens Alexander Spitzer et Viktor Frankl et les polonais Lucja Frey et Wladyslaw Sterling. En ravivant le souvenir de ces neuroscientifiques, nous leur rendons hommage et prévenons que l'humanité n'oublie cette tragédie, de peur que cette période sombre de l'histoire ne se répète.
\end{abstract}

Can J Neurol Sci. 2012; 39: 729-746

In Part I, ${ }^{1}$ several European neuroscientists ${ }^{\mathrm{a}}$ were discussed who were collaborators with the Nazi "euthanasia" programs from 1939-1945 that resulted in about 275,000 murders of neurologic and psychiatric patients, ${ }^{2-5}$ or those who engaged in unethical and brutal human experiments. In Part II, several European neuroscientists who openly and actively, or passively and ambivalently, resisted the Nazi regime were discussed. ${ }^{6}$ Other German neuroscientists were dismissed from their positions due to Nazi laws enacted after Adolf Hitler's takeover in January 1933 (in Austria after March 1938, and in other European countries after German occupation in World War II), and many emigrated to other countries throughout Europe and the rest of the world. Though the majority of German physicians emigrated from Nazi Germany prior to the Holocaust, ${ }^{7}$ many neuroscientists became victims of the Nazis. In this paper, the focus is on the latter group and we address the circumstances that led to this massive tragedy to our specialty and to humanity as a whole. While reflecting on the overall context in their various countries, we discuss in depth seven exemplary neuroscientist Holocaust victims, including Germans Ludwig
Pick, Arthur Simons, and Raphael Weichbrodt, Austrians Alexander Spitzer and Viktor Frankl, and Poles Lucja Frey and Wladyslaw Sterling. This comprehensive analysis of the victims from our specialty, to our knowledge, has not previously been undertaken to this extent.

\section{Anti-Semitism in German Medicine}

The Nazi "Law for the Reconstitution of the Civil Service" (Gesetz, zur Wiederherstellung des Berufsbeamtentums), passed

see footnote for ${ }^{a}$ on following page

From the Department of Neurology and Rehabilitation (LAZ), University of Illinois at Chicago, Chicago, Illinois, USA; Department of Neurology (DK), Rigshospitalet, Copenhagen University Hospital, Copenhagen, Denmark.

Received June 7, 2012. Final Revisions Submitted July 24, 2012.

Correspondence to: Lawrence A. Zeidman, University of Illinois at Chicago,

Department of Neurology and Rehabilitation (M/C 796), Neuropsychiatric Institute,

912 S. Wood Street, Room 855N, Chicago, Illinois, 60612-7330, USA.

Email: lzeidm1@uic.edu. 
on April 7, 1933, , was not the beginning of Anti-Semitism toward German neuroscientists. Herman Oppenheim (18581919) was one of the leading clinical neurologists of the 19th century $^{8}$ and was initially only appointed to the rank of Privatdozent, or university lecturer, with the title of professor but in name only and unsalaried. ${ }^{9}$ Despite publishing his seminal "Textbook of Nervous Diseases for Doctors and Students," a comprehensive myasthenia gravis monograph (among many other international publications), ${ }^{10}$ and having the unanimous support of the medical faculty of the Berlin University, his nomination to succeed Carl Westphal (1833-1890) and become Neurology Chair in 1890 was rejected by the Prussian Ministry of Education because he was Jewish. He was advised that the decision was possibly reversible if he were to be baptized, but he refused. ${ }^{11}$ Max Lewandowsky (1876-1916), editor of the Handbuch der Neurologie, and co-editor of the Zeitschrift fur die gesamte Neurologie und Psychiatrie (Comprehensive Journal of Neurology and Psychiatry), and Hugo Liepmann (1863-1925), neuropsychiatrist and director of the insane asylum in BerlinHerzberge, are other examples of prominent Jewish neuroscientists who had their academic careers hindered because of their Judaism. ${ }^{12}$

Pre-Nazi era anti-Semitic remarks toward German and Austrian Jewish neuroscientists were frequently recorded. ${ }^{13}$ Famed German neurologist Wilhelm Erb (1840-1921) stated in reference to a publication on tabes dorsalis by Isaac and Koch that "these equally uncritical and brazen Jewish scalawags have earned a rough beating." 14 Erb also wrote, "It is necessary to make every effort that the Jewification of our society does not take on larger dimensions." 15 In the discussion about Erb's successor in 1920, it was said that he "locked out Semites."16 Nobel prize-winning Viennese neuropsychiatrist Julius WagnerJauregg (1857-1940) wrote of Johann Paul Karplus (1866-1936), an Austrian Jewish neuroscientist, that "Karplus is a Semite, but neither his appearance nor his demeanor gives this away..."17 German neuroscientist Friedrich Schultze (1848-1934) (coeditor, Deutsche Zeitschrift für Nervenheilkunde, German Journal for Neurology), complained "that Neurology [has] so predominantly fallen to the house of Sem."18 About psychiatrist/neurologist Oswald Bumke (1877-1950), Hugo Spatz (1888-1969) wrote that "Bumke didn't like having Jews as assistants, at least those who were unbaptized." ${ }^{19}$ Despite his assistance and sympathy toward some Jewish colleagues, 6,13 famous German neurologist Max Nonne (1861-1959) was no philosemite. Regarding Jewish neurologist Robert Wartenberg (1887-1956) (who later emigrated to the USA in the 1930s), who was Nonne's assistant in 1922, Nonne wrote, "Mr. Wartenberg is a particularly unsympathetic man. For almost a year he was voluntarily in my department and was as Jewish as one can be..." 20 These examples demonstrate that although a GermanJewish symbiosis was achieved, it was tension-fraught, and racial hatred and conceit were part of everyday life for Jews by the end of the 1920s. Neuroscientists participated in this antiSemitism as well. This may explain why, besides the mere struggle for jobs, there was no widespread resistance to the expulsion of neuroscientists from their positions in the $1930 \mathrm{~s}^{21}$

In 1933, 6500 Jewish doctors lived in Germany, or 8-9 000 if one includes other non-Aryans (baptized Jews, Mischlinge (part-Jews), and other minorities), and political dissidents. ${ }^{7}$ That 8-9 000 comprised $15-17 \%$ of 52500 German physicians, ${ }^{7,22}$ not the $48 \%$ grossly exaggerated by the Nazis. ${ }^{7}$ About 2/3 (4 500 to $6000)$ of Jewish physicians emigrated to other countries, and up to $5 \%$ committed suicide. The rest, $25 \%$ (over 2000 ) by conservative estimates, were murdered by the Nazi Holocaust machinery. ${ }^{7}$ In the "biocracy" of Nazi Germany, the eventual goal was to remove the "parasitic" infection of Judaism from the German blood, and Hitler was seen as the "national healer." Jewish doctors were antithetical to the goals of the Nazi state, in that they preserved Jewish life. In the ideal Third Reich, doctors served as "racial wardens," healing the German people and not just the individual patient. Jewish doctors were incapable of fulfilling this role, and thus were marginalized. Additionally male Jewish doctors were vilified as sexual predators, and this propaganda was used to classify them as "felons" instead of "colleagues." Other motivations for Nazi persecution included economical ones and career opportunism. Many younger "Aryan" doctors slandered Jewish colleagues in attempts to take their jobs, or to be offered now vacant spots on insurance panels. Personal vendettas were also a rationale for attacks on Jewish colleagues, under the guise of Nazi principles. ${ }^{7}$

Against this backdrop, the Nazis wanted some "legal cover" for their persecution of Jewish physicians and their extirpation from power. The Nazis engaged in a step-wise reduction of professional rights of Jewish physicians soon after they assumed power. Jewish civil servant, or public university, physicians (Amtsärzte) were the first to lose their positions after the Nazis passed the previously mentioned Reconstitution Law. ${ }^{7}$ Because it had the largest Jewish population, and the largest number of Jewish physicians, ${ }^{7}$ Berlin was an example of the devastation the Nazi regime directed toward Jewish doctors. In Berlin, Jews were only $5 \%$ of the population as a whole, but comprised $1 / 3$ of all physicians. Jewish teachers and professors at universities often lacked legal status and were unsalaried. ${ }^{22}$ Berlin's Charité Hospital is exemplary for the transition of German medical academia under the reign of the Nazi party. In an act of "anticipatory obedience" following Nazi propaganda, all Jewish staff were dismissed on April 1, 1933, six days prior to enactment of the Reconstitution Law. Out of 331 lecturers, 135 (41\%) were immediately forbidden from further teaching. ${ }^{23}$ Another source stated that 139/334 (42\%) Charité professors were dismissed. ${ }^{24}$ Their positions were taken by regime-faithful "Aryan" colleagues. ${ }^{23}$ After 1933 in Berlin, 100\% of the physicians at Lankwitz Hospital were dismissed for racial reasons, 67\% at the Neuköllner Hospital, 62\% at the Friedrichshain Hospital, and $56 \%$ at the Moabit Hospital. ${ }^{25}$ Sixty-two primarily Jewish clinical neurologists, psychiatrists, psycho-pathologists, and psychotherapists (most were neuropsychiatrists in the German tradition of combining both

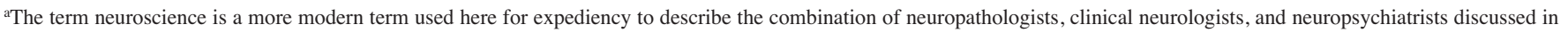
this paper, though the term didn't exist in the 1930's and 40's. 
specialties) were dismissed in Germany after 1933 according to a 1936/37 list. ${ }^{26}$ Some of those dismissed in Berlin were notable directors of neurology clinics, including Kurt Goldstein, F.H. Lewy, Paul Schuster, Clemens Ernst Benda, Otto Maas, and Kurt Löwenstein. $^{12}$

Further legislative marginalization took place on April 22, 1933, when "non-Aryan and communist physicians" were informed that they no longer would be reimbursed by public health insurance organizations. ${ }^{23}$ Later, private insurance contracts with Jewish doctors were also abrogated. Thus, many of the dismissed lecturers and hospital clinicians had to rely on private practices, with patients paying "out of pocket," or look for different sources of income to make a living. Also, nonAryan physicians were prohibited from collaborating with Aryan physicians. "Hindenburg exemptions" to the Reconstitution Law and to the insurance contract abrogations applied to physicians who had initiated their practice prior to August 1, 1914, those who had served on the front line during World War I (WWI), those who had lost a father or son in WWI, or those who had exposed themselves to lethal epidemics in quarantine camps. Despite the exemptions, however, often dismissals were made and the physicians had to fight to become reinstated, but by then, their patients had often chosen another doctor. ${ }^{7}$ Some neurologists, such as Alfred Hauptmann (1881-1948) in Halle, who had a decorated WWI record and was in the military reserve, and neuropsychiatrist Karl Stern (1906-1975) of Munich, who had an American Rockefeller research grant, were able to delay dismissal transiently. ${ }^{27}$

Life for Jewish and other non-Aryan doctors became increasingly difficult, despite the fact that in some cities by 1935 , over $50 \%$ of the public insurance doctors were still Jewish (mainly because of the Hindenburg exemptions). Arbitrary and capricious physical and non-physical terror reigned throughout Germany against non-Aryan doctors after 1933, meted out by the SS (Schutzstaffel, Nazi black shirts), SA (Sturmabteilung, Nazi brown shirts), Gestapo (Nazi secret police), and backed by Nazi physicians. Graffiti was painted outside Jewish doctors' offices, round-ups of Jewish doctors (sometimes with shooting to kill or maim) took place, and arrests for minor offenses or trumped-up charges (eg, writing an incorrect prescription, or vague charges of subversion) took place. On July 7, 1933, neurologist Dr. Kauffmann was arrested in Berlin along with others, and imprisoned for four days. The doctors were told they had been in "protective custody" and should return if they feel threatened again. Other arrests and beatings of Jewish doctors lead to deaths directly, or suicides. ${ }^{7}$ Thus, the precarious legality and daily torture affecting all Jews in the Reich should have been portentous of tragedy ahead. With the Nuremburg Race Laws of September 15, 1935, all full Jews lost their Reich citizenship and were merely "residents" of Germany. Since "non-citizens" could not maintain a civil service position, all Jewish civil servant academic physicians, previously exempt from the 1933 Reconstitution Law, were now summarily dismissed.

The penultimate disenfranchisement came on July 25, 1938 which stipulated all Jewish doctors would be decertified by September 30. By early 1939 there were only 285 practicing Jewish doctors in the entire German Reich. ${ }^{7}$ As delicensed physicians, they were derogatorily called Krankenbehandler (therapists of sick people), and could only treat Jewish patients. ${ }^{7,23}$ The economic advantages gained from this final expulsion were freely admitted by Nazi physicians. Further, the Reich Physician's Chamber tried to exclude as many former Jewish doctors from retirement pensions as possible. Additionally, Jews were compelled to surrender their passports in October, 1938, hampering any international travel and, in December 1938, they were forbidden the use of automobiles, including revocation of their driver's licenses. The latter action obviously restricted any doctors on call from seeing their patients. $^{\text {? }}$

The well-orchestrated Nazi pogroms throughout Germany and in Vienna, on November 9 and 10, 1938, referred to as Kristallnacht (Night of Broken Glass), especially targeted Jewish doctors, as they exclusively treated ill Jews and saved Jewish life, contrary to Nazi goals ("anti-genocidal"). These pogroms were an extension of the capricious violence that many practitioners had already experienced. It was very risky even for "legitimate" Jewish "sick-treaters" to practice medicine in the days surrounding Kristallnacht; if they didn't go temporarily into hiding, they could be immediately arrested and sent to a concentration camp. ${ }^{7}$ Overall, roughly 30,000 Jewish men were arrested and incarcerated in camps following Kristallnacht, but they were released if they agreed to leave Germany and cede their property to "Aryans." 28 Some doctors committed suicide, and some were murdered outright by marauding Nazi bullies. Wounded Jews hospitalized after attacks also were not safe, as raiding SS, SA, and Gestapo Nazis assaulted Jewish patients and doctors and destroyed medical equipment. Most of the Kristallnacht calamities died down by early 1939, but legal and sanctioned illegal atrocities toward Jewish doctors did not end. Of the more than 2000 Jewish doctors still left in Germany by October 1941, when SS Reichsführer Heinrich Himmler forbade further emigration, only a few survived the Holocaust. ${ }^{7}$ Table 1 lists 27 clinical neurologists deported from Berlin and murdered by the Nazi regime.

\section{Anti-Semitism in Austrian Medicine}

Austrian and Austro-Hungarian anti-Semitism was more deeply ingrained into society than in Germany, and Hitler took many of his tenets from turn-of-the-century Vienna. ${ }^{7}$ Thus, the anti-Semitism and persecution of Austrian neuroscientists did not start with the Anschluss (forced annexation) to Nazi Germany in March, 1938. Unification of Austrian intellectuals with the ideas of "Pan-Germanism" and its ideals of success at any price, and war as the "creator of all things," dated back to the 1870s. Jews, Marxists, liberals, pacifists, democrats, and Catholics who did not accept this pan-Germanic attitude were vogelfrei (without protection), at Austrian universities. By 1923, with some exceptions in the Medical Faculty, even very brilliant Jews were clandestinely excluded from teaching careers, because of an unwritten rule denying them Habilitation (postdoctoral thesis to attain the highest academic qualification). Many prominent senior faculty members at the University of Vienna were members of the secret Deutsche Gemeinschaft, an organization that circulated lists of Jewish and other ideologically-unacceptable faculty in an attempt to thwart their careers, and by 1929, the University of Vienna had "become virtually an enclave of the Third Reich." Many Austrian intellectuals disregarded daily evidence of Nazi violence and 
Table 1: Berlin Jewish Neurologists, deported and killed in Nazi concentration camps ${ }^{\mathrm{a}}$

\begin{tabular}{|c|c|c|c|c|c|}
\hline Name & Date, place of birth & Title, place, date of thesis & $\begin{array}{l}\text { Main site of professional } \\
\text { occupation }\end{array}$ & $\begin{array}{l}\text { Date of } \\
\text { transportation }\end{array}$ & Concentration camp ${ }^{\mathrm{b}}$ \\
\hline Alexander, Frieda & 1891, Heide, Holstein & $\mathrm{n} / \mathrm{a}^{\mathrm{c}}$ & Private practice & 12.03 .1943 & Auschwitz \\
\hline Bermann, Ferdinand & 1868, Frankfurt & On traumatic neurosis. Strasbourg 1892 & Unknown & $\begin{array}{l}\text { 26.09.1942, } \\
\text { Treblinka }\end{array}$ & Minsk (ghetto) \\
\hline Epstein, Frieda & 1899, Eichstätt, Bavaria & On spastic spinal paralysis. Berlin 1926 & Unknown & 28.06 .1943 & Auschwitz \\
\hline Flatau, Georg & 1865, Lyck, East Prussia & $\begin{array}{l}\text { On the treatment of tabes dorsalis. Berlin } \\
1890\end{array}$ & $\begin{array}{l}\text { Hospital-based; editor of German } \\
\text { neurological journal }\end{array}$ & 02.09 .1942 & Theresienstadt \\
\hline Flörsheim, Ernst & 1872, Berlin & n/a & $\begin{array}{l}\text { Director, Division for prisoners } \\
\text { with mental handicap, Prison } \\
\text { Berlin-Moabit }\end{array}$ & 01.02 .1944 & Bergen-Belsen \\
\hline Goldstein, Martin & 1877, Breslau & $\mathrm{n} / \mathrm{a}$ & Unknown & 26.09 .1942 & $\begin{array}{l}\text { Raasiku/Reva (killing } \\
\text { field) }\end{array}$ \\
\hline Guttmann, Leo & 1870, Breslau & $\mathrm{n} / \mathrm{a}$ & Unknown & 19.04 .1943 & Theresienstadt \\
\hline Haake, Bruno & 1874, Berlin & $\begin{array}{l}\text { A case of carcinoma metastasis involving the } \\
\text { cortex and the skull base. Leipzig } 1905\end{array}$ & Hospital-based, private practice & 18.06 .1942 & Theresienstadt \\
\hline Haber, Toni & 1880, Berlin & $\begin{array}{l}\text { A case on the hereditary occurrence of } \\
\text { multiple sclerosis. Berlin } 1922\end{array}$ & Unknown & 03.10 .1942 & Theresienstadt \\
\hline $\begin{array}{l}\text { Hirschfeld, Hans } \\
\text { Hirsch }\end{array}$ & 1873, Berlin & $\mathrm{n} / \mathrm{a}$ & $\begin{array}{l}\text { Hospital-based neurologist, later } \\
\text { professor for hematology }\end{array}$ & 30.10 .1942 & Theresienstadt \\
\hline $\begin{array}{l}\text { Hirsch-Tabor, Otto } \\
\text { Simon }\end{array}$ & 1876, Augsburg & $\mathrm{n} / \mathrm{a}$ & Unknown & 03.10 .1942 & $\begin{array}{l}\text { Raasiku/Reval (killing } \\
\text { field) }\end{array}$ \\
\hline Jaffé, Martin & 1899, Dramburg, Pomerania & $\mathrm{n} / \mathrm{a}$ & Private practice & 29.11 .1942 & Auschwitz \\
\hline Kaufmann, Max & 1861, Deutsch-Krohne, West Pomerania & $\mathrm{n} / \mathrm{a}$ & Unknown & 12.06 .1942 & Theresienstadt \\
\hline Kempner. Alfons & 1878, Bromberg, Pomerania & $\mathrm{n} / \mathrm{a}$ & Unknown & 03.10 .1942 & Theresienstadt \\
\hline Kirchstein, Antonie & 1898, Berlin & $\mathrm{n} / \mathrm{a}$ & Unknown & 15.08 .1942 & Riga \\
\hline Laufer, Kurt & 1894, Berlin & $\mathrm{n} / \mathrm{a}$ & Hospital-based & 15.06 .1942 & Sobibor \\
\hline Levy, Ernst Nathan & 1885, Hamburg & $\mathrm{n} / \mathrm{a}$ & Private practice, hospital-based & 03.10 .1942 & Theresienstadt \\
\hline Marx, Moritz & 1875, Wiesbaden & On partial color blindness. Freiburg 1898 & Unknown & 16.05 .1944 & Auschwitz \\
\hline Münzer, Arthur & 1882, Vienna & $\mathrm{n} / \mathrm{a}$ & Private practice & 12.10 .1944 & Auschwitz \\
\hline $\begin{array}{l}\text { Rattner, Zacharias } \\
\text { H. }\end{array}$ & 1878, Memel, East Prussia & $\mathrm{n} / \mathrm{a}$ & Unknown & 06.03 .1943 & Auschwitz \\
\hline Ruben, Walter & 1885 Berlin & $\begin{array}{l}\text { Psychogenic psychoses in war participants. } \\
\text { Rostock } 1919\end{array}$ & Unknown & $\begin{array}{l}\text { 03.10.1942, } \\
\text { Theresienstadt }\end{array}$ & Bergen-Belsen \\
\hline Salomon, Erich & 1889, Iserlohn, Westphalia & $\mathrm{n} / \mathrm{a}$ & Unknown & 09.12 .1942 & Auschwitz \\
\hline $\begin{array}{l}\text { Schlesinger, Erich } \\
\text { Gustav }\end{array}$ & 1876, Leobschütz, Upper Silesia & $\begin{array}{l}\text { The anatomy of the lower spinal cord. } \\
\text { Leipzig } 1902\end{array}$ & Unknown & 09.03 .1943 & Theresienstadt \\
\hline Simons, Arthur & 1877, Düsseldorf & $\begin{array}{l}\text { On head posturing and muscle tonus; } \\
\text { habilitation. Berlin } 1921\end{array}$ & Professor, Charité & 03.10 .1942 & $\begin{array}{l}\text { Raasiku/Reval (killing } \\
\text { field) }\end{array}$ \\
\hline $\begin{array}{l}\text { Singer, Kurt } \\
\text { Bernhard }\end{array}$ & 1885, Gdansk & $\mathrm{n} / \mathrm{a}$ & $\begin{array}{l}\text { Hospital-based neurologist, later } \\
\text { professor at the Berlin Academy } \\
\text { of Music }\end{array}$ & 22.04 .1943 & Theresienstadt \\
\hline Strauß, Hermann & 1868, Heilbronn & $\begin{array}{l}250 \text { cases of hemiplegia and on the functional } \\
\text { difference of the hemispheres. Berlin } 1890\end{array}$ & Hospital-based, professor & 31.07 .1942 & Theresienstadt \\
\hline Wolff, Ernst & 1886 Guttentag, Upper Silesia & $\mathrm{n} / \mathrm{a}$ & Private practice & 03.10 .1941 & Theresienstadt \\
\hline
\end{tabular}

aJewish neurologists (Nervenärzte) with license issued by the German health insurance funds and with main professional engagement in Berlin, as listed in contemporary German registries (Reichsarztregister, Reichsärzteverzeichnis); data compiled from Schwoch R (ed.) Berliner jüdische Kassenärzte und ihr Schicksal im Nationalsozialismus: Ein Gedenkbuch. Hentrich \& Hentrich, 2009; ${ }^{b}$ the site of deportation is also the documented or presumed place of death; the

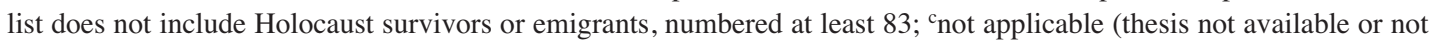
related to the neurosciences)

obstinately believed that the "true" Germany couldn't be guilty of the atrocities recounted by German émigrés and the foreign press. ${ }^{29}$ Some Jewish academics refused to believe "Austria could sink into barbarity," and refused to emigrate and accept positions abroad, 29,30 but others did emigrate from Vienna between 1934 and $1938 .^{31}$

After March, 1938, Austrian Jewish physicians were subjected to all the legal and illegal tortures and disenfranchisement their German colleagues had experienced. The persecution of Austrian Jewish doctors may have been more merciless because the Nazis suspected more of the hated "Eastern Jewry" (eg, from Polish Galicia, once part of Austro-Hungary) were among their ranks. The Nazis charged that more than $50 \%$ of Austrian doctors were Jewish, ${ }^{7}$ and $75 \%$ of the total in Vienna (though only $8 \%$ of Vienna's population). ${ }^{7,32}$ Another source states that in 1938, 3 200/4 900 (65\%) of Viennese physicians were Jewish according to Nazi statistics. ${ }^{31}$ Indeed, Jewish doctors surpassed other Austrian professionals as victims. Capricious violence, murders, arrests, and suicides took place. Frequently in Vienna, Jewish doctors were chased out of offices after they were immediately dismissed, and were made to perform pejorative tasks while their "Aryan" servants observed comfortably. ${ }^{7}$ The purge of Jewish faculty at the University of Vienna Medical School resulted in 153/197 faculty members (78\%) losing their positions, virtually destroying medical education. ${ }^{29}$ Another source stated that more than 132/197 (67\%) of Jewish or "uncertain origin" scholars were dismissed. Most of these were Privatdozenten. Twenty-six of those 132 dismissed $(20 \%)$ were neurologists, neuropsychiatrists, or neuropathologists. ${ }^{31}$ By the spring of 1939 , about 2000 Jewish doctors had been removed from Austrian society. ${ }^{7}$ At least 12 University of Vienna faculty later died in Nazi death camps, and between three and six committed suicide in $1938 .^{29}$ Table 2 lists 11 Austrian and Czech neuroscience victims of the Nazis.

\section{Anti-Semitism in Polish Medicine}

In Poland, Jews faced the most discrimination in public service professions and in many liberal professions such as education; thus most Polish Jewish intellectuals turned to law and medicine. In 1926, Jews made up $40.5 \%$ of all Polish physicians, and comprised $46 \%$ of all Polish private medical practitioners in 1931. Anti-Semitism against Polish Jewish 
physicians went through two phases. Before 1935, Jewish doctors had difficulty obtaining ordinarius positions in university clinics or public hospitals, and medical school graduates had difficulty obtaining year-long internships required for public or university appointments. Jewish physicians were also underrepresented as practitioners on health insurance funds in Poland. Even pre-eminent Jewish neurologists Samuel Goldflam (1852-1932) and Edward Flatau (1869-1932) were not granted teaching positions. The University of Warsaw contained no Jewish medical faculty members, and while several Jews attained dozent (instructor) status, none was ever promoted to associate professor or higher. ${ }^{33}$ Goldflam in 1893 described three patients with myasthenia gravis, two years before Friedrich Jolly coined the disease name. ${ }^{\text {b } 8,34}$ Goldflam was denied directorship of his own neurology service in Warsaw, and was restricted to treating only outpatients or seeing consultations on patients under the care of his non-Jewish colleagues. He set up a private practice as a means of supporting himself, like many of his Jewish colleagues, including a special clinic for poor Jewish patients which he funded himself. It was from patients seen in this special clinic that he collected the three for his case series on myasthenia. ${ }^{8}$

After 1935, Polish Jewish doctors could not even attain dozent status in university clinics, and Jews were barred from presenting papers at medical conferences. They experienced hostility if they tried to take part in discussions there. Jewish hospitals were threatened with liquidation, with claims from anti-Semitic authorities that Jewish patients could be treated at general hospitals (where they were frequently treated poorly). These closures also threatened employment of Jewish medical school graduates who could not obtain hospital positions elsewhere. In 1937, the Union of Polish Physicians passed the "Aryan paragraph" resolution stating that only "Poles of Polish descent" could be members, which was later toned down by the government to "Polish citizens of Christian birth" to preserve an illusion that it was independent from Nazi influence. In 1938, the Union resolved that Jews would be barred from medical school admission until their proportion in medicine conformed to their proportion in the general population. Moreover, enlargement of medical departments to accommodate more non-Jewish young Poles would occur, medical chambers would exclude non-Poles, and "nostrification" of foreign medical diplomas held by Jews would be ceased. Later that year it was recommended that Jewish doctors using Slavic or Christian names should be penalized, Jews should not be granted any government or municipal positions, they should not be employed as court experts, and they should be required to display an indentifying mark on their shingles. ${ }^{33}$ Table 3 lists 38 Polish neuroscientists victimized by the Nazis in the Holocaust.

\section{RESULTS}

Ludwig Pick (1868 - 1944) - Born in Landsberg/Warthe (today Gorzów Wielkopolski, Western Poland). (Figure 1) He studied medicine in Heidelberg, Leipzig, Berlin, and Königsberg, and in 1909 became a professor of pathology at Friedrichshain Hospital in Berlin. As a German army volunteer during WWI he served as a senior medical officer, and was decorated with several Medals of Honor, including the RedCross Medal, 3rd class, and Iron Cross Medals, 1st and 2nd class. Pick was internationally renowned and was invited to give lectures in Sweden, Great Britain, and the US. In 1921 he became an honorary professor at Berlin's Friedrich-Wilhelm

Table 2: Viennese and Prague Neuroscience Victims of the Nazis

\begin{tabular}{|c|c|c|c|c|}
\hline $\begin{array}{l}\text { Name and birth and } \\
\text { death dates }\end{array}$ & $\begin{array}{l}\text { MD place } \\
\text { and/or date }\end{array}$ & Neurology training/position & $\begin{array}{l}\text { Viennese } \\
\text { Neurologic School }\end{array}$ & Fate \\
\hline $\begin{array}{l}\text { Bruno Fischer } \\
(1888-1973)\end{array}$ & $\begin{array}{l}\text { Prague, } \\
\text { 1911? }\end{array}$ & Assistant, Prague 1911-25; 1925-39 Lecturer and Specialist in Neurology, Prague & Arnold Pick & $\begin{array}{l}\text { Deported to Theresienstadt in } \\
1942 \text {, Auschwitz inmate 1943-45, } \\
\text { survived war }\end{array}$ \\
\hline $\begin{array}{l}\text { Oskar Fischer } \\
(1876-1942)\end{array}$ & $\begin{array}{l}\text { Prague, } \\
1900\end{array}$ & $\begin{array}{l}\text { Assistant, Prague 1902-19; } 1906 \text { Lecturer in Psychiatry; 1917-39 Assoc. Prof. in Prague; } \\
\text { 1908-19 Clinical Laboratories, Prague; 1920-39, Head, Weleslavin Sanatorium, Prague }\end{array}$ & Arnold Pick & Died in Theresienstadt \\
\hline $\begin{array}{l}\text { Viktor E. Frankl } \\
(1905-1997)\end{array}$ & $\begin{array}{l}\text { Vienna, } \\
1930\end{array}$ & See text & $\begin{array}{l}\text { Otto Pötzl, Josef } \\
\text { Gerstmann }\end{array}$ & See text \\
\hline $\begin{array}{l}\text { Erwin Hirsch } \\
(1888-1944)\end{array}$ & $\begin{array}{l}\text { Prague, } \\
1919 ?\end{array}$ & $\begin{array}{l}\text { Assistant, Prague 1919-29; 1928-38 Lecturer in Psychiatry, Prague; } 1929-38 \text { spa doctor at } \\
\text { Karlsbad (Haus Venus) }\end{array}$ & Otto Pötzl & $\begin{array}{l}\text { Deported to Theresienstadt in } \\
\text { 1942, died in Auschwitz }\end{array}$ \\
\hline $\begin{array}{c}\text { Ernst Kalmus } \\
(1869-1942)\end{array}$ & $\begin{array}{l}\text { Prague, } \\
1894\end{array}$ & $\begin{array}{l}\text { Assistant, Prague 1896-99, 1900-? Police doctor, court psychiatrist, Lecturer at College of } \\
\text { Education; 1919-38, Lecturer of industrial sanitation/hygiene in Prague }\end{array}$ & Arnold Pick & Died in Auschwitz \\
\hline $\begin{array}{l}\text { Vojtech Adalbert Kral } \\
(1903-1988)\end{array}$ & $\begin{array}{l}\text { Prague, } \\
1927\end{array}$ & $\begin{array}{l}\text { Assistant in Psychiatric Clinic, Prague 1928-34, } 1930 \text { Zurich, } 1931 \text { German Research Inst. } \\
\text { For Psychiatry, Munich, 1933 Pharmacology Institute and Psychiatric Clinic, Vienna; 1934, } \\
\text { court psychiatrist, Prague; 1934-39 Lecturer Psychiatry and Neurology, Prague }\end{array}$ & Eduard Gamper & $\begin{array}{l}\text { 1939, dismissed; deported to } \\
\text { Theresienstadt, inmate 1942-45, } \\
\text { survived war }\end{array}$ \\
\hline $\begin{array}{l}\text { Leopold Kramer } \\
\text { (1865-1944?) }\end{array}$ & Prague & Assistant, Prague 1886-94, Head of private hospital for nervous disorders Prague-Bubentsch & Arnold Pick & $\begin{array}{l}\text { Deported to Theresienstadt in } \\
\text { 1942, died in Auschwitz }\end{array}$ \\
\hline $\begin{array}{l}\text { Max Löwy } \\
(1875-1948)\end{array}$ & $\begin{array}{l}\text { Prague, } \\
1900\end{array}$ & $\begin{array}{l}\text { Assistant, Prague 1902-09; } 1919 \text { Lecturer in psychiatry and neurology, Prague; 1924-38, } \\
\text { Assoc. Prof. in Prague; 1902-39, Spa doctor and court psychiatrist at Marienbad, 1903-14- } \\
\text { court psychiatrist in Eger }\end{array}$ & Arnold Pick & $\begin{array}{l}\text { Deported to Theresienstadt, } \\
\text { inmate 1942-45, survived war }\end{array}$ \\
\hline $\begin{array}{l}\text { Franz Theodor Münzer } \\
\text { (1895-1944?) }\end{array}$ & $\begin{array}{l}\text { Prague, } \\
1920\end{array}$ & $\begin{array}{l}\text { 1922-25 unpaid laboratory assistant at the psychiatric clinic in Prague; } 1928-39 \text { Lecturer in } \\
\text { psychiatry and neurology; } 1937-39 \text { Specialist in Neurology in Prague }\end{array}$ & Otto Pötzl & $\begin{array}{l}\text { Deported to Theresienstadt in } \\
\text { 1942, died in Auschwitz }\end{array}$ \\
\hline $\begin{array}{l}\text { Otto Sittig } \\
(1886-1944)\end{array}$ & $\begin{array}{l}\text { Prague, } \\
1910\end{array}$ & $\begin{array}{l}\text { Assistant, Prague 1911-24, 1918-19 in Berlin, 1919-20 neurology in Frankfurt am Main; } \\
1921 \text { Lecturer in psychiatry and neurology in Prague; 1931-39 Assoc. Prof.; 1925-31 unpaid } \\
\text { laboratory assistant at the psychiatric clinic in Prague }\end{array}$ & Arnold Pick & $\begin{array}{l}\text { Deported to Theresienstadt in } \\
\text { 1943, died in Auschwitz }\end{array}$ \\
\hline $\begin{array}{l}\text { Alexander Spitzer } \\
\text { (1868-1943) }\end{array}$ & $\begin{array}{l}\text { Vienna, } \\
1892\end{array}$ & See text & $\begin{array}{l}\text { Richard Krafft- } \\
\text { Ebing, Heinrich } \\
\text { Obersteiner }\end{array}$ & See text \\
\hline
\end{tabular}

${ }^{\mathrm{b}}$ For many years myasthenia gravis was known as Erb-Goldflam disease, also for Wilhelm Erb. ${ }^{8}$ 
Table 3: Polish neurologist victims in the Third Reich ${ }^{\text {a }}$

\begin{tabular}{|c|c|c|}
\hline Adolf Beck (1863-1942; died in Lviv) & $\begin{array}{l}\text { Ludwik Eliasz Bregman (1865-1941; died in } \\
\text { Warsaw ghetto) }\end{array}$ & $\begin{array}{l}\text { Aleksander Domaszewicz (1887-1948; survived } 8 \text { months in } \\
\text { Pawiak prison, Warsaw) }\end{array}$ \\
\hline $\begin{array}{l}\text { Wladyslaw Dzierzynski (1881-1942; } \\
\text { publicly executed in Lodz together } \\
\text { with } 100+\text { Polish intellectuals) }\end{array}$ & $\begin{array}{l}\text { Henryk Dynkiewicz (1898-?; deported from } \\
\text { Warsaw ghetto, lost) }\end{array}$ & $\begin{array}{l}\text { Bronislaw Frenkel (1887-1943; committed suicide by } \\
\text { poisoning when arrested by Gestapo) }\end{array}$ \\
\hline $\begin{array}{l}\text { Lucja Frey (1889-1943; died in Lviv; } \\
\text { see text) }\end{array}$ & $\begin{array}{l}\text { Ignacy Fuhrman (1889-?; murdered together } \\
\text { with his wife in Lviv by Gestapo) }\end{array}$ & $\begin{array}{l}\text { Helena Katz-Furhmanowa (1895-?; murdered together with } \\
\text { her husband in Lviv by Gestapo) }\end{array}$ \\
\hline $\begin{array}{l}\text { Adam Graddzinski (?-1943; shot by } \\
\text { Gestapo) }\end{array}$ & $\begin{array}{l}\text { Henryk Higier (1866-1942; killed by Gestapo } \\
\text { in Warsaw ghetto) }\end{array}$ & $\begin{array}{l}\text { Stanislaw Romuald Zygmunt Higier (1894-1942; son of H. } \\
\text { Higier; murdered by Nazi officers) }\end{array}$ \\
\hline $\begin{array}{l}\begin{array}{l}\text { Roman Kaufer (1885-?; lost during } \\
\text { WWII) }\end{array} \\
\end{array}$ & $\begin{array}{l}\text { Waclaw Jezewski (1892-1952; survived camp } \\
\text { internation) }\end{array}$ & Stanislaw Justman (1874-1942; suicide in Warsaw ghetto) \\
\hline $\begin{array}{l}\text { Abraham Kacenelson (1893-1944; } \\
\text { deported from Warsaw ghetto) }\end{array}$ & Gottfryd Kaczanowski (1905-?; died in Lviv) & Bernhard Eugeniusz Kalwaryjski (1890-?; killed by Gestapo) \\
\hline $\begin{array}{l}\text { Jozzef Kirschner (1898-?; died in } \\
\text { Warsaw ghetto) }\end{array}$ & $\begin{array}{l}\text { bian Klozenberg (1876-1944; died in Lodz } \\
\text { etto })^{\mathbf{b}}\end{array}$ & Henryk Lastman 1899-?; killed by Nazi officers) \\
\hline $\begin{array}{l}\text { Stefan Lesniowski (1893-1943; killed } \\
\text { accidentally during street shooting in } \\
\text { Warsaw) }\end{array}$ & $\begin{array}{l}\text { Jozef Limanowski (1899-1939; died as Polish } \\
\text { military officer in battle) }\end{array}$ & Leon Lipszowicz (1897-?; killed by Nazi officers) \\
\hline $\begin{array}{l}\text { Elzbieta Litauer-Wojdyslawska (?-?; } \\
\text { killed by Nazi officers) }\end{array}$ & $\begin{array}{l}\text { Wladyslwa Medynski (1892-1942; died of } \\
\text { heart attack while under arrest by Gestapo) }\end{array}$ & Maks Orlinski (1892-1944; killed by Nazi officers) \\
\hline $\begin{array}{l}\text { Kazimierz Orzechowski (1878-1942; } \\
\text { died of heart attack in Warsaw ghetto) }\end{array}$ & $\begin{array}{l}\text { Jakub Pinczewski (1893-?; killed by Nazi } \\
\text { officers) }\end{array}$ & $\begin{array}{l}\text { Salomea Bau-Prusakowa (1889-1942; deported from Warsaw } \\
\text { ghetto to Treblinka extermination camp) }\end{array}$ \\
\hline $\begin{array}{l}\text { Izydo Rein (1898-?; killed by Nazi } \\
\text { officers) }\end{array}$ & $\begin{array}{l}\text { Samuel Rozental (1909-1940; died in } \\
\text { Warsaw ghetto) }\end{array}$ & $\begin{array}{l}\text { Wladyslaw Sterling (1876-1943; shot together with his wife in } \\
\text { bed by Gestapo; see text) }\end{array}$ \\
\hline $\begin{array}{l}\text { Zdzislaw Tomaszek (1890-?; lost } \\
\text { during WWII) }\end{array}$ & $\begin{array}{l}\text { Mieczyslaw Urbach 81910-1944; deported } \\
\text { from Lodz ghetto; likely killed in Auschwitz) }\end{array}$ & $\begin{array}{l}\text { Markus Wajnberg (1891-1945; deported from Lodz ghetto to } \\
\text { Dachau concentration camp) }\end{array}$ \\
\hline $\begin{array}{l}\text { Maurycz Wolff (1900-1943; killed } \\
\text { during Warsaw ghetto uprising }\end{array}$ & $\begin{array}{l}\text { Natalia Zylberlast-Zandowa (1883-1941; } \\
\text { killed by Nazi officers) }\end{array}$ & $\begin{array}{l}\text { as cited in Herman E: Neurolodzy Polscy. Warsaw, } \\
\text { Panstwowy Zaklad, } 1958 \\
\text { b as cited in Jaroszewksi Z (ed): Zaglada chorych psychicznie } \\
\text { w Polsce 1939-1945. Wydawnictwo Naukowe PWN } 1993\end{array}$ \\
\hline
\end{tabular}

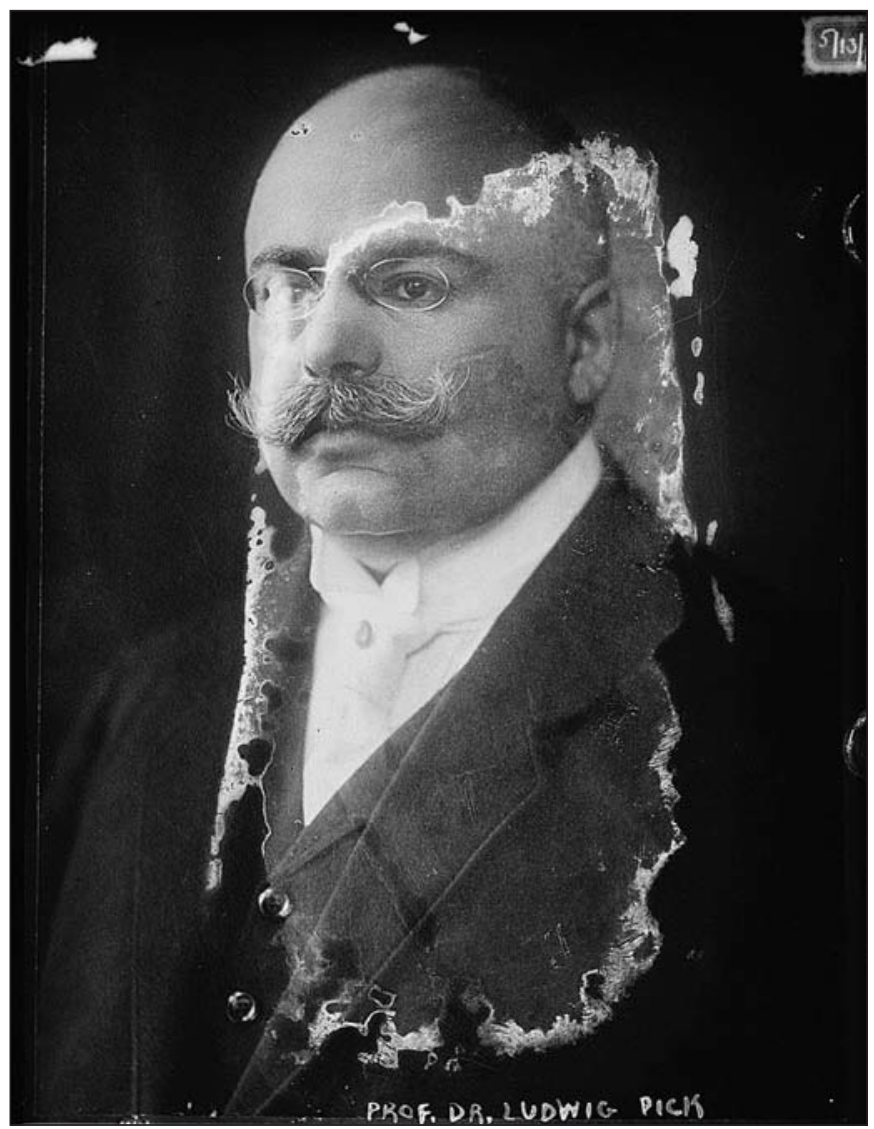

Figure 1: Ludwig Pick, 13 May 1912. Part of the George Grantham Bain Collection, Library of Congress, Washington, DC. This photo is now in the public domain and is posted on www.commons.wikimedia.org.
University. In addition to Niemann-Pick disease A-C (lysosome storage diseases with sphingomyelin accumulation), he has been honored with several eponyms unrelated to the neurosciences (e.g., Lubarsch-Pick amyloidosis, Pick retinitis). He was Harvey Lecturer in London in 1932 and Dunham Lecturer at Harvard Medical School in Boston in 1931-32. Pick refused professorships in Chicago and Shanghai in 1933 because he felt "still, as ever before...bound to my German Fatherland despite these hard times." 35

In April 1933, Pick was questioned about the "racial origin of his grandparents," and he answered, "all of mosaic faith." According to Nazi terminology this made him a Volljude (German, for a "full Jew"). Despite Pick's distinguished WWI record, the public officer handling his case listed him as not having served in the war because he didn't have "direct confrontation with the enemy." In 1933, a few weeks before the Reconstitution Law came into power, Pick was officially discharged into retirement at Friedrichshain Hospital. His successor was Franz Büchner (1895-1991), who later became one of the few prominent German physicians who spoke out against Nazi euthanasia. Büchner allowed Pick to continue his scientific work at the institute for another year; however, Pick, "the kind, distinguished and helpful person had to leave our institution in 1934 only because he was a Jew." On February 22, 1936, Pick was informed that he was dismissed as lecturer at the university. The letter from the head of the university included neither a salutation nor a word of thanks. "I want to emphasize that for the time being you may keep the title of honorary professor but [when using it] you have to include a statement that you are no longer a member of the Medical Faculty." (Figure 2) In the subsequent semester course catalogue Pick was listed as "at present on leave." After 1934, Pick worked at Cecilienhaus Institute that belonged to the health insurance funds in Berlin; he had no official employment. Pick's last scientific publication dates from 1935, in which he did not list any affiliation. ${ }^{35}$ 


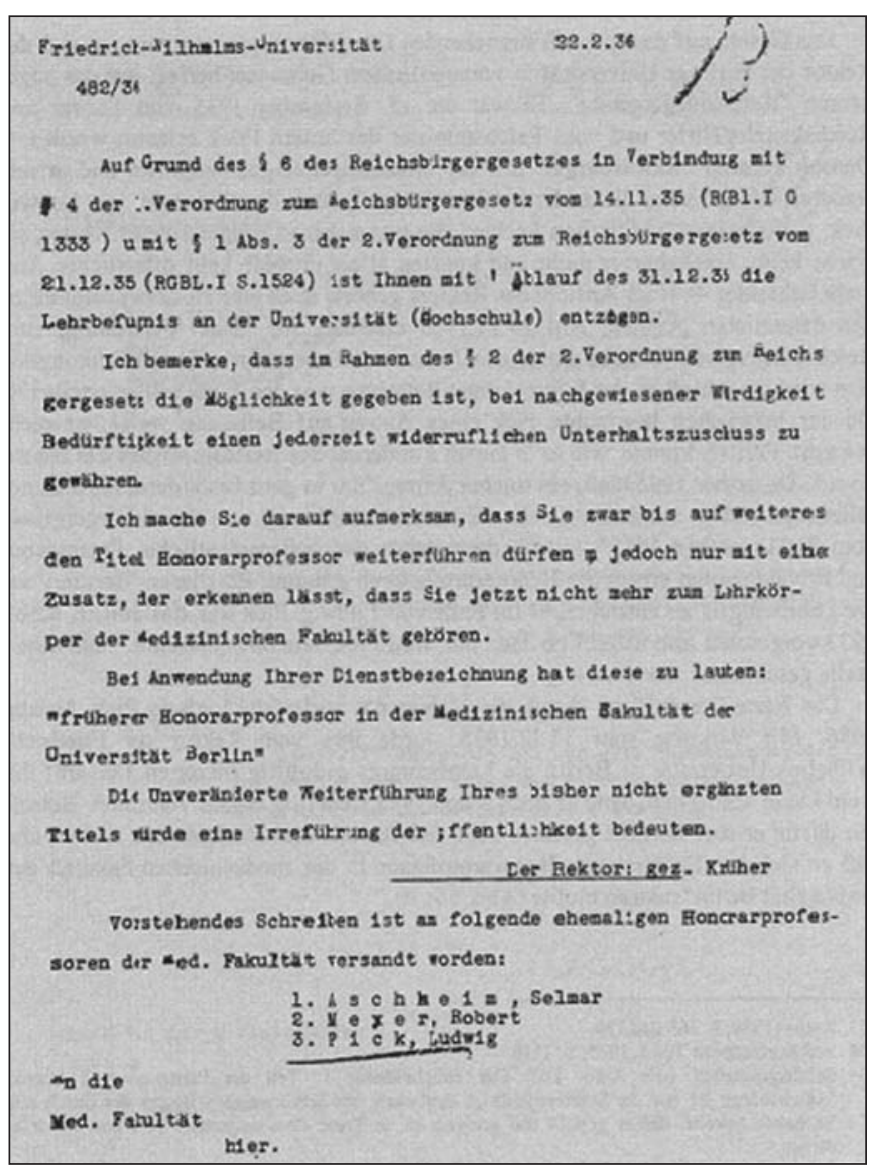

Figure 2: Dismissal Notice, Ludwig Pick, February 1936. Reprinted with permission from the Universitätsarchiv, Humboldt Universität zu Berlin.

For most of his life Pick had been a confirmed bachelor, stating "Love is a psychosis that always may be given a good prognosis." 36 Yet, following his forced retirement, he fell in love with the non-Jewish nurse Anna König (1891-1967) but the Nazi Nuremberg Laws prohibited the planned wedding in 1936. The same year, Pick bought a plot of land in Berlin-Zehlendorf and built a house (Jews were prohibited from acquiring real estate two years later). There, König and Pick lived in a marriage-like liaison, though König kept her own apartment to maintain the facade. Pick's brother, who had moved to the US the same year, tried to persuade Pick to follow him, but he had no plans to flee Germany. According to his fiancée, "He did not consider it thinkable that the racial cleansing committed by the Nazis would eventually affect him too. Even in the years of war when the displacing of Jews started my fiancé did not reckon with his deportation." 35

In August 1938 Pick began working as unpaid head of the Pathological Institute of the Jewish Hospital in Berlin-Wedding. Four months later he was stripped of his medical license and was henceforth degraded to a Krankenbehandler. ${ }^{37}$ Following a 1938 decree (Einführung kennzeichnender Vornamen, 17 August 1938) forcing Jews without "typical" Jewish names to adopt the middle names "Israel," respectively, or "Sarah," Pick was officially registered as "Ludwig Israel Pick." After Kristallnacht, Pick developed severe depression, and in a state of denial of the outside world, fully concentrated on his clinical work. Beginning in September 1941, Pick had to wear the yellow badge that all Jews were ordered to sew on their outer garments to mark them in public. ${ }^{35}$

On March 16, 1943 Pick and König were arrested by the Gestapo, but she was released three weeks later. Like most of the few remaining Jews in Berlin, Pick was taken into custody in the very same Jewish Hospital in Berlin-Wedding in which he previously had been head of the pathological department. Eight days prior to his deportation, Pick's remaining assets were transferred to a Nazi bank account "in favor of [...] the Reich's Association of the Jews in Germany, marked 'Retirement home, board and lodgings."' Thus, similar to many other Jews, Pick was forced to finance his livelihood in a concentration camp. ${ }^{35}$ On June 16, 1943 Pick's train (Altentransport I/96) left for Theresienstadt ghetto. ${ }^{\mathrm{c}}$ This train carried 430 of the last Volljuden of the Jewish community in Berlin, which had been declared by the Gestapo as "officially extinguished" six days earlier. Only 81 of the train passengers survived the war. ${ }^{38}$ Pick died on February 3, 1944 from pneumonia. ${ }^{35}$

Arthur Simons (1877-1942) - Born in 1877 in Düsseldorf, Simons received a medical degree in 1903 after studies in Heidelberg, Munich, and Berlin. After having various clinical positions, some of them unpaid, ${ }^{39}$ he worked from 1907 to 1914 under Oppenheim at the Friedrich Wilhelm University in Berlin. ${ }^{40}$ In 1911 Simons described a young female with upper body lipodystrophy, ${ }^{41}$ which later came to be known as Barraquer-Simons syndrome. ${ }^{42}$ Simons referenced Spanish neurologist Lluis Barraquer-Roviralta's original 1907 paper $^{43}$ while writing his own, but was the first to include a picture of a patient with the syndrome, and also the first to objectively explore the syndrome's etiology. ${ }^{42}$ Simons, using metabolic tests, hypothesized that the syndrome was due to tuberculosis, whereas Barraquer-Roviralta thought it was caused by a sympathetic derangement. During WWI Simons served as a medical officer, ${ }^{40}$ and he managed to publish several manuscripts on data derived from field observations on soldiers with traumatic brain injury, notably a report on tonic neck reflexes associated with hemiplegia. ${ }^{40,44-46} \mathrm{He}$ innovatively documented these observations in a series of short motion pictures. ${ }^{40}$ (Figure 3 )

In 1921 Simons became lecturer, and in 1923, professor of neurology at the Charité Hospital, Humboldt University, Berlin. ${ }^{38}$ Like most of his Jewish colleagues at that time, he was professor extraordinary (German, außerordentlich; not regular). This meant for Simons a much more unsecure financial and professional situation compared to ordinary professors who received their salary from the university. Simons, therefore, also maintained a private medical office in Berlin from 1931 to

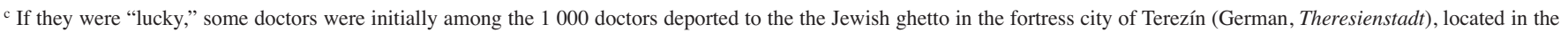

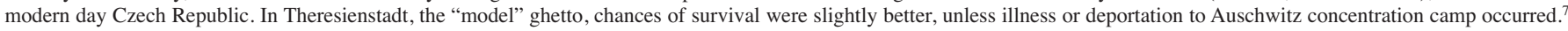




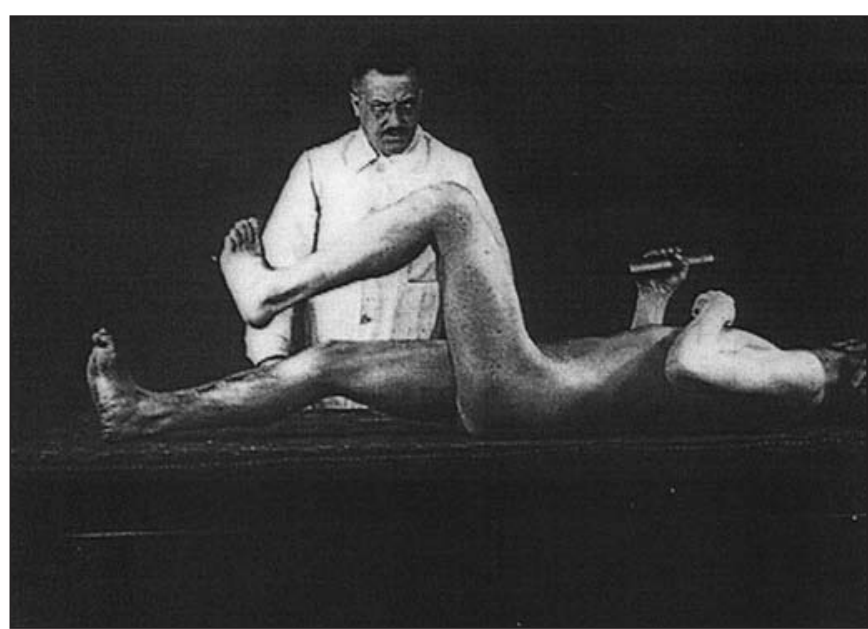

Figure 3: Video clip from 1919 showing Arthur Simons and a patient with left hemiparesis. The patient turns his head to the right and makes a fist with his right hand, which induces co-movements of the hemiplegic left body, specifically flexion and adduction of the arm (including hand closing) and hip and knee flexion, along with foot elevation. From Holdorff BE. Schriftenreihe der Deutschen Gesellschft für Geschichte der Nervenheilkunde 2012;18:371-389. Courtesy of BundesarchivFilmarchiv, Berlin, and provided by Prof. Bernd Holdorff, Deutsche Gesellschaft für Geschichte der Nervenheilkunde, Germany.

1939. ${ }^{38}$ In September 1933 Simons was dismissed from his Charité office because of the Nazi Reconstitution Law (Figure 4). In August 1938 the Jewish community board recommended Simons to be chief of the neurological division of Jewish health care in Berlin. It remains unknown whether the Berlin Medical Board accepted this proposal. ${ }^{38}$ After 1939, Simons was listed as a Krankenbehandler. ${ }^{38}$ Attempts to emigrate to the UK failed. Simons was arrested by the Gestapo in September 1942 and detained at one of the collecting points in Berlin for Jews prior to their deportation. He was deported to Raasiku, Estonia either on 26th September ${ }^{39}$ or 3rd October 1942.38 Upon arrival at Raasiku station, some victims were selected for forced labor and interned at Jägala concentration camp. However, the majority, including Simons, were executed at Raasiku killing field. 38-39

Raphael Weichbrodt (1886-1942) - Born in Łabiszyn, Poland into a wealthy but provincial merchant family, and studied medicine in Berlin, Munich, Heidelberg, and Freiburg. (Figure 5) In 1913 he became a psychiatry resident at Charité University Hospital, Berlin. He also had a keen interest in writing literature, and wrote comedies, libretti and poems, but his manuscripts never become available to a larger public. Weichbrodt had a very liberal, even indifferent approach toward Judaism, was antiZionist, and desired to assimilate in Germany. In 1915 he accepted an offer from the Mental and Epilepsy Asylum in Frankfurt, but then served as a military physician during WWI. ${ }^{47}$

After the war, he wrote several neurologic papers, including Experimental studies on Salvarsan therapy of syphilitic

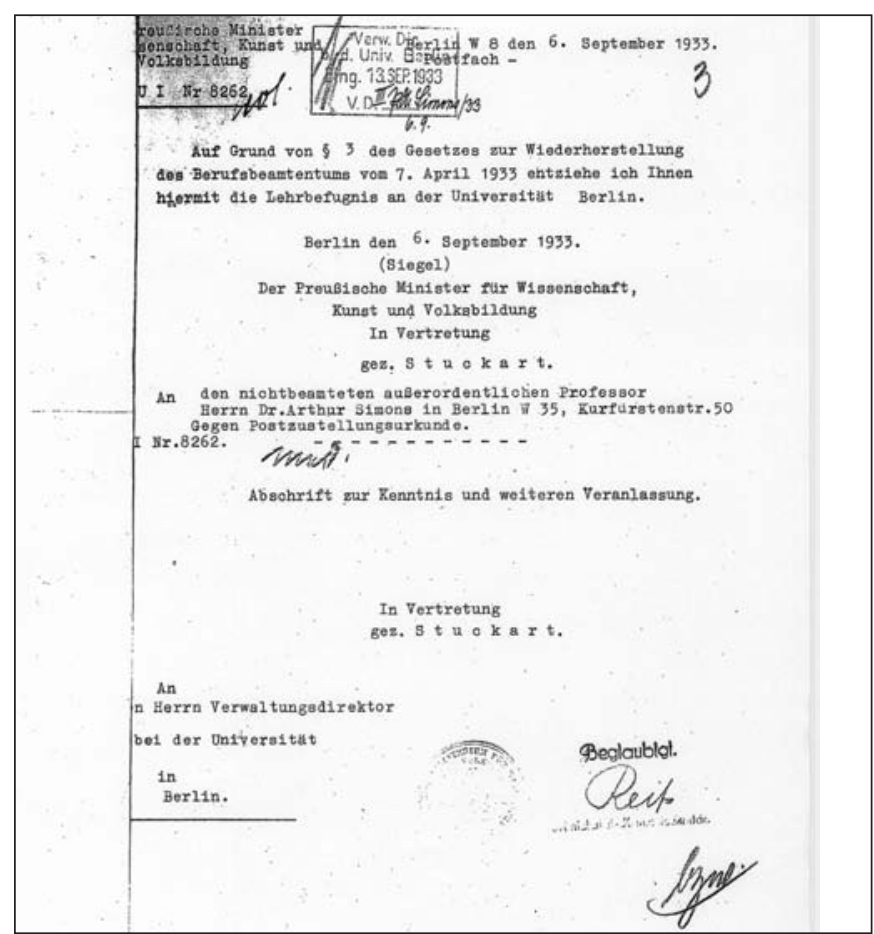

Figure 4: Dismissal Letter, Arthur Simons, 1933. Reprinted with permission from the Universitätsarchiv, Humboldt Universität zu Berlin.

paralysis, ${ }^{48}$ On the Wassermann test in syphilitics, ${ }^{49}$ On the interactions of blood and cerebrospinal fluid, ${ }^{50}$ and On dementia praecox during childhood. ${ }^{51}$ In 1921 he became a lecturer of psychiatry and neurology at Frankfurt University. Earning various royalties and expert testimony fees (as well as a lesser university salary), Weichbrodt had the economical means to quit the Mental Asylum. In 1926, he became professor at Frankfurt University. In 1932 he became the head of the ChemicalSerological Laboratory of the Municipal and University Hospital for Mental and Nervous Diseases. Yet suddenly, his fate changed for the worse.

In April 1933, Weichbrodt was dismissed from his university post as required by the Reconstitution Law, despite his objection. The anti-Semitic periodical Der Weltkampf published a list of dismissed Frankfurt scientists (including Weichbrodt and Ernst Herz, another Frankfurt lecturer of psychiatry and neurology) and commented, "The outrageous Jewish infiltration of German Universities becomes distressingly obvious when considering the list of lecturers dismissed from Frankfurt University (...). To have left the education of our youth so fully to Semitic racial inferiority (German, semitisches Niederrassentum), this is a crime of [the Weimar Republic] worthy of death." 52 In the winter semester 1933/34 course catalogue Weichbrodt was listed as "at present on leave." The Nazi laws making medical practice difficult, combined with the Nazi Editor's Law (German,

${ }^{\mathrm{d}}$ Nazi law of October 4, 1933 stating that Jewish doctors could not publish their works in German books or journals. ${ }^{27}$ 


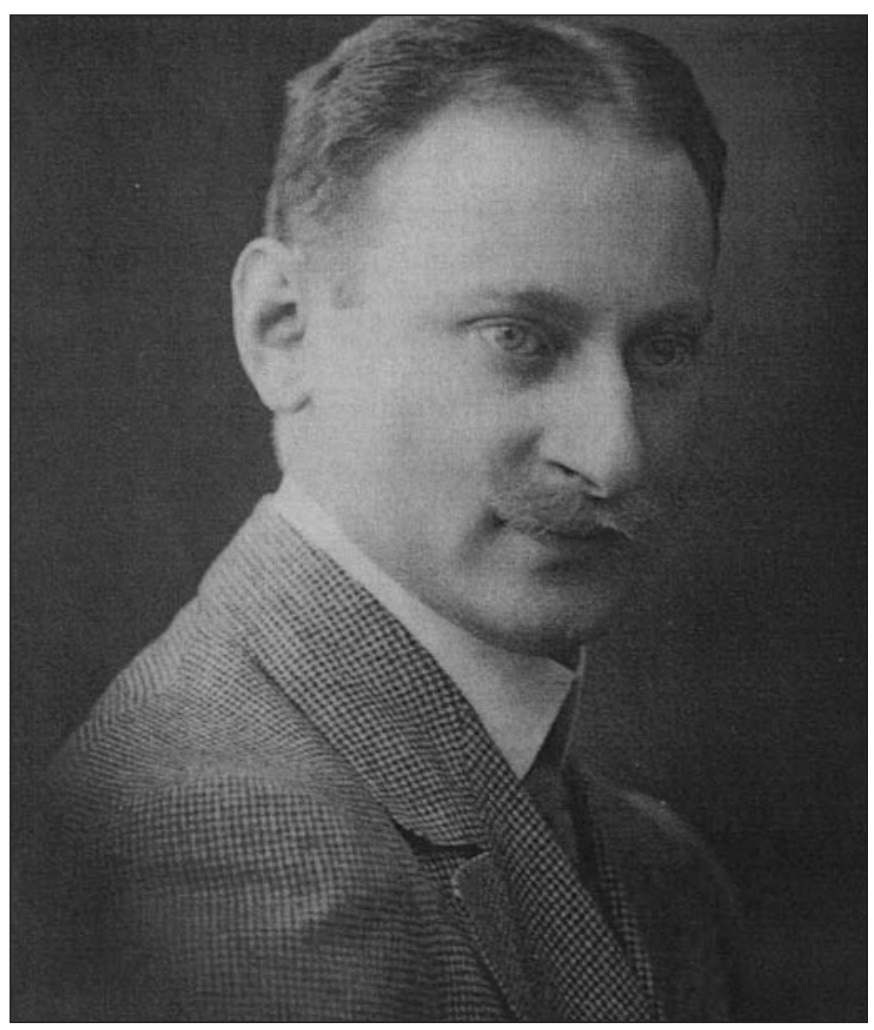

Figure 5: Raphael Weichbrodt, ca. 1912. Published in Schäfer K. Verfolgung einer Spur (Raphael Weichbrodt). Frankfurt am Main: Fritz Bauer Institut; 1998. Reprinted with permission.

Reichsschriftleitergesetz), ${ }^{\mathrm{d}}$ largely destroyed Weichbrodt's professional life. Although his eldest daughter and several other relatives emigrated, Weichbrodt stayed in Frankfurt and concentrated on several book projects. His opus magnum, "The Suicide," was published after four years delay in neutral Switzerland.$^{53}$ Without any other regular income Weichbrodt was heavily dependent on the royalties, which turned out to be disappointingly minimal. ${ }^{47}$

On 27 October 1938 he received a note from the Frankfurt police headquarters that his passport would be withdrawn. Following the Nazi introduction of obligatory "Semitic" surnames, he became "Raphael Israel Weichbrodt." He stayed in Frankfurt together with his daughter, and like all German Jews was forced to pay Judenvermögensabgabe, a collective fine of one billion marks for the destruction which had occurred during Kristallnacht. At this time his income from a small pension and support from his daughter did not cover half the costs of daily living. Nevertheless, like all other Jews he was also charged a "security tax" (Sicherungsabgabe, 23 February 1939). The same year he received a note from the UK with an invitation to emigrate; for unknown reasons this offer was not accepted. ${ }^{47}$

A broken man, Weichbrodt no longer left his flat. His friend, Oscar Quint, provided him with fruits, vegetables and occasionally some money. Although Quint was well-aware of being followed, in May 1942 he and Weichbrodt were surprised by two Gestapo constables. They were informed that they soon would be "relocated." Quint did not dare come back to his friend's place until 17 June 1942, only to find that Weichbrodt's apartment had been sealed and that his friend was gone. Weichbrodt had been deported on 24 May 1942 together with 930 others toward the East. Whereas Weichbrodt's date of death seems certain (31 May 1942), this is not the case for the place of death. According to one source he died in Gross-Rosen concentration camp, Silesia. ${ }^{39}$ But according to another source he died in Mauthausen concentration camp, Austria. ${ }^{54}$

Alexander Spitzer (1868-1943) - Born in Miskolc, Hungary, and attended the University of Vienna Medical School, graduating in $1892 .{ }^{55}$ (Figure 6) He then worked in Richard Krafft-Ebing's (1840-1902) Psychiatric Clinic from 1893$1901,55,56$ and also trained in neurology under Heinrich Obersteiner (1847-1922) in Vienna. ${ }^{56} \mathrm{He}$ worked independently before becoming an assistant at the First Anatomical Institute at the University of Vienna from 1914-19. Then he joined the Vienna Institute in Neurology under Otto Marburg (1874-1948), and in 1924 became Associate Professor of Anatomy and Physiology of the Nervous System at the University of Vienna, where he remained until 1933. ${ }^{55,56} \mathrm{He}$ later became Extraordinary Emeritus Professor (German, Emeritierter außerordentlicher Professor).

In Spitzer's early career, he published many works in neurology, including on the physiology of the posterior longitudinal fasciculus, ${ }^{57}$ migraines,${ }^{58}$ on an abnormal brainstem tract,,${ }^{59}$ and on the genesis of the crossing of the pyramidal tracts in vertebrates. ${ }^{60}$ In 1924 , he published papers on the central nervous system anatomy and physiology of the vestibular

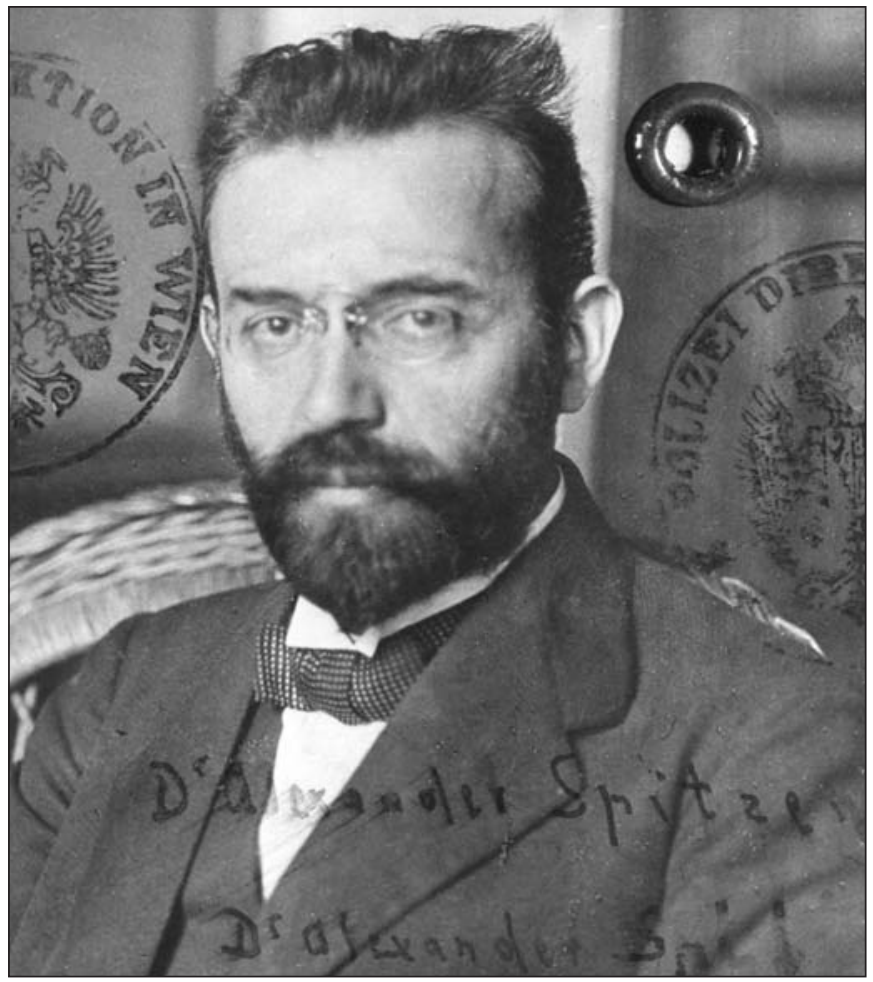

Figure 6: Alexander Spitzer, unknown year. Courtesy of the Archive of the University of Vienna, Vienna, Austria. Reprinted with permission. 


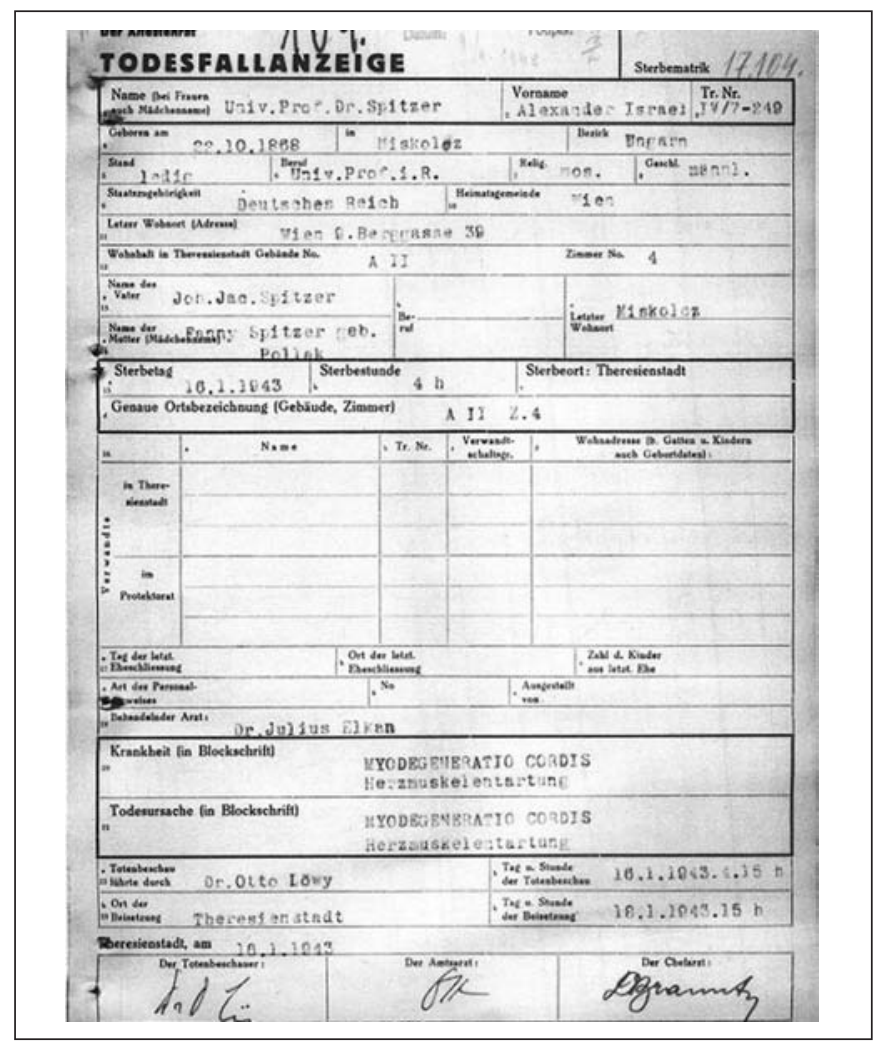

Figure 7: Ghetto Theresienstadt Death Notice, Univ. Prof. Dr. Alexander Spitzer. Reprinted with permission from the Holocaust Institute, Prague.

tracts, ${ }^{61}$ and on the function of the semicircular canals. ${ }^{62} \mathrm{He}$ then published further papers on embryology and comparative anatomy in relation to phylogenetics. ${ }^{55}$ Spitzer seems to have applied his broad philosophical, mathematical, and biological knowledge base to his work, and merged philosophy with science, which arguably brought to it both strength and weakness. ${ }^{55}$ His work suffered criticism during his lifetime. Beside criticism regarding his hypothesis on migraine pathophysiology, ${ }^{63}$ his cardiac embryology theory also came under fire in 1933 from Dr. Eduard Pernkopf at the University of Vienna, ${ }^{55}$ later Dean of the Medical School and a fanatical member of the Nazi party and SA who was a major instigator of the purging of Jewish staff from the medical school. ${ }^{64}$

Spitzer's lectures were apparently well-received by his students, and he was noted by friends to be considerate, kind, and have a fine sense of humor. But he was vitriolic, belligerent, and defensive toward those who criticized him, and devoted a considerable amount of time against them, especially against Pernkopf. ${ }^{55}$ Following the Nazi Anschluss in 1938, he was thrown out of the University. He was still living in Vienna (Figure 7), but it is unknown whether he worked after that time. Like Pick and Weichbrodt, he was forced by the Nazis to adopt the "Israel" middle name and was referred to as "Alexander Israel Spitzer." (Figure 7) It is known that on August 14, 1942, Spitzer was deported by the Nazis to Theresienstadt concentration camp on transport IV/7.65 $\mathrm{He}$ was already suffering from cardiac disease, and died at the camp on January 16, 1943. ${ }^{29,55,65}$ (Figure 7)

Viktor Emil Frankl (1905-1997) - Born in Vienna, and as early as junior high attended psychoanalytic lectures given by neurologist and psychiatrist Paul Schilder (1886-1940). ${ }^{\mathrm{e}}$ Frankl also corresponded with psychiatrist and neurologist Sigmund Freud (1856-1939) when he was just a high school student. Frankl created a new psychological theory, that of logotherapy, which was referred to by some as "the Third Viennese School of Psychotherapy" (Freud's and Alfred Adler's being the other two). ${ }^{66}$ Logotherapy is based in existential analysis and as opposed to the Freudian "will to pleasure" and Adlerian "will to power," considers the main human motivation to be the "will to meaning." A contradictory fact regarding Frankl's history usually omitted from biographies involves his participation from 1936-38 in the Austrian branch of the Nazi-sponsored Goering Institute (German Institute for Psychological Research and Psychotherapy), an organization to which he may have contributed out of opportunism, self-protection, and naiveté. He warned against using psychotherapy for ideological and nonmedical purposes, but claimed that leading German psychotherapists were already cautionary toward this point, which was not true. ${ }^{67}$

After graduation from the University of Vienna Medical School in 1930, Frankl worked under Otto Pötzl (1877-1962) in the University Neuro-Psychiatric Clinic, and subsequently under Josef Gerstmann $^{\text {f }}$ (1887-1969) at the Maria Theresien Schlössel Neurological Hospital. He then worked for four years at Am Steinhof Psychiatric Hospitalg in Vienna. In 1937, Frankl opened his own practice in neurology and psychiatry. However, after the Anschluss, Frankl was not allowed to continue his private practice, and lost his Goering Institute connection, but was offered a position as Judischer Fachbehandler (Jewish Specialist) at the Rothschild Hospital (Vienna's Jewish Hospital) in 1940. (Figure 8) This was one of the few places Jews could work in Vienna, and he eventually became Director of Neurology. ${ }^{66,67}$ This post afforded him and his parents some protection from deportation to concentration camps. ${ }^{66}$ Rothschild was under Nazi authority as of April, 1939, and was intermittently raided by the SS. ${ }^{67}$ Frankl claimed to have been able to help the staggering numbers of suicidal Jewish patients at that desperate time in the early 1940s, up to ten per day. Frankl also related a story with a "tragicomical element," in which he treated a young man's epilepsy, eliminating his seizures, but he was then prone to fits of rage, including a public tirade against Hitler. Frankl immediately took him off the anti-epileptic, as the seizures were less life-threatening than the alternative! ${ }^{66}$

Frankl apparently became involved in experimental neurosurgical procedures at Rothschild, ${ }^{66}$ which has garnered recent posthumous criticism. ${ }^{67}$ Without any mention of whether

${ }^{\mathrm{e}}$ He described Schilder's Disease, a severe progressive variant of multiple sclerosis. ${ }^{\mathrm{f}}$ He described Gerstmann's Syndrome, the dominant angular gyrus syndrome, as well as codescribing Gerstmann-Sträussler-Scheinker Syndrome. ${ }^{\mathrm{g}}$ Am Steinhof, and its pediatric hospital Am Spiegelgrund, would later become a site for Nazi euthanasia murders. 


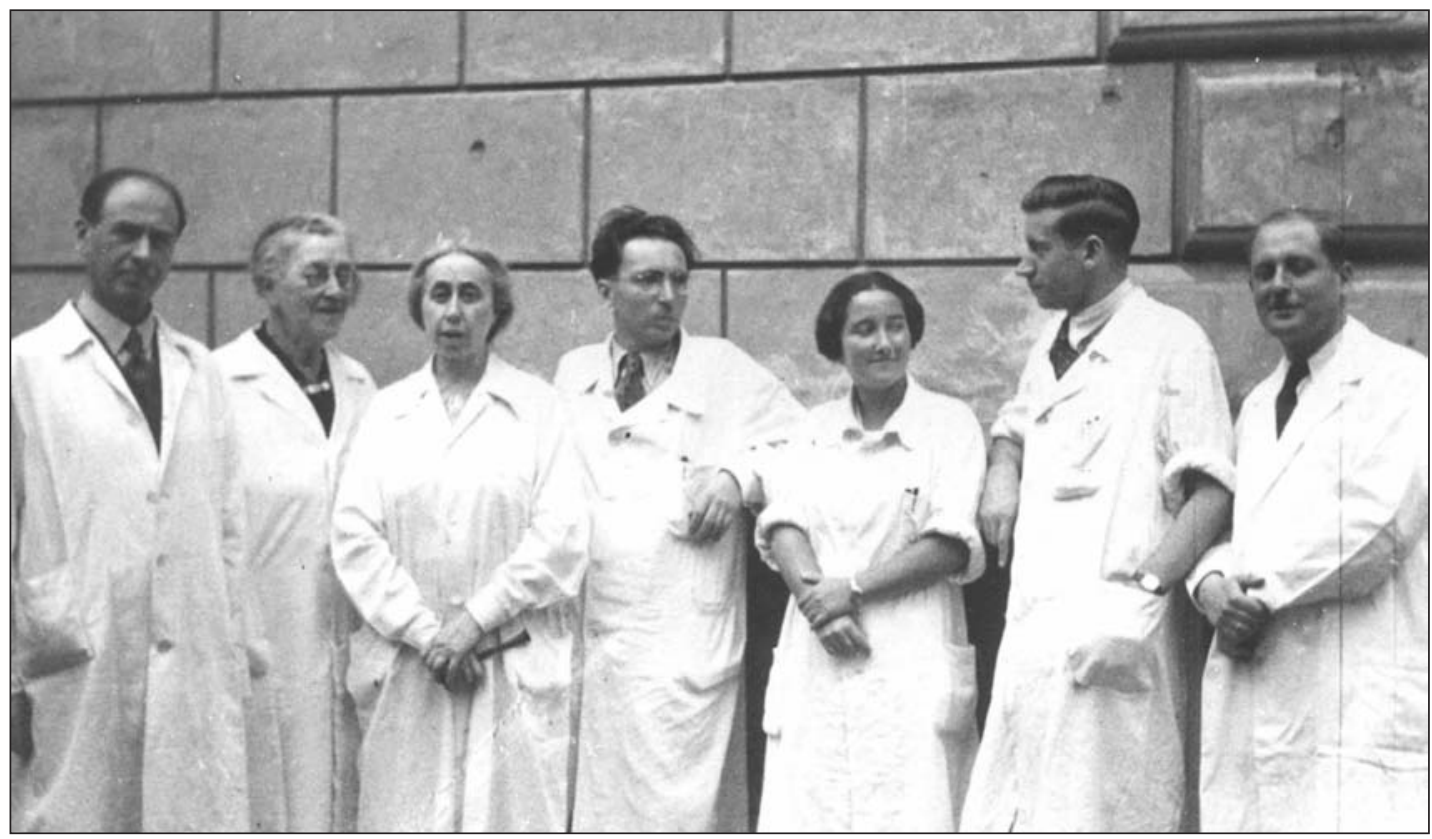

Figure 8: Viktor E. Frankl (middle), with staff of Rothschild Hospital in 1940. Standing third from left is his assistant, Dr. Rappaport, whose life he tried to save when she attempted suicide on notice of her impending deportation. Reprinted with permission from the DÖW (Documentation Center of Austrian Resistance), Vienna, Austria.

informed consent was obtained from families of comatose Jewish suicidal patients (though he felt treatment emergent and informed consent was not standardized at the time), and without any proper neurosurgical training (he was barred from observing surgical cases at Rothschild), he "trephinated" these patients to inject amphetamines directly into the lateral ventricles. This was following initial unsuccessful attempts at intravenous or intracisternal injections of amphetamines. He learned of the trephination (technical aspects only, but his amphetamine injection was novel) from reading papers by Walter Dandy, the famous American neurosurgeon. ${ }^{67} \mathrm{He}$ had seen improved respiration previously in Guillain-Barré patients with respiratory and bulbar failure after administering amphetamines via a suboccipital puncture into the cisterna magna. But the lateral ventricle injection he felt would more directly deliver stimulants to the brainstem reticular activating system on drainage through the Aqueduct of Sylvius. ${ }^{68}$ His justification was that the physician's task was to preserve life at any cost, and not to "play G-d," although his procedures were antithetical to the patient's obvious wishes and the natural clinical course. Indeed, the "Masada solution," or suicide, was chosen by approximately 1200 Viennese Jews during the Nazi era, especially among the upper-middle-class, and Frankl broke with Jewish communal solidarity and the protests of his own assistant Dr. Rappaport (Figure 8) (who Frankl ironically later saved from her own suicide attempt when she found out she would be deported, which she then later was) by saving the lives of suicidal Jews, who were then deported by the Nazis. ${ }^{66,67}$ Frankl stated, "I do respect the decision of people to end their lives. But I also wish others respect the principle that I have to save lives as long as I am able." ${ }^{66}$ Besides disregarding his patients' wishes in light of the extreme circumstances, Frankl also apparently did not test the experimental procedures on animals first, which may have been prudent given prior experimental evidence (of which Frankl was likely unaware) on dogs from 1918 that any chemical solution with a slight alkalinity or acidity injected into the cerebral ventricles would cause a severe reaction, always with fatal results, thus likely not being a justifiable treatment. ${ }^{67}$ Frankl's neurosurgical research was published in neutral Switzerland in 1942, ${ }^{68}$ despite Nazi-imposed entanglements for Jewish doctors in the Reich to publish research. In 'off the cuff' remarks in 1972, Frankl stated that although "I was put in the concentration camps before I could finish the research..." that "...the National Socialists hoped that this [research] could be tried and used in war, in combat, in the case of their soldiers. That is why they even encouraged me to publish it in Switzerland, so that they may read it in a journal. Only for this I thank this possibility to publish it." ${ }^{69}$ Frankl's life-saving mantra toward suicidal Jews, as well as his neurosurgical research, were in line with Nazi policies ${ }^{70}$ of sadistically attempting to prevent Jewish suicides, and after waiting for them to recover, deporting them to their systematic murder. Frankl was certainly influenced by therapeutic idealism in his attempts to save lives at any cost, arguably contradictory to his attempt not to "play G-d," and may have been academically opportunistic in publishing his article. But whether he simply coincidentally acted in parallel to Nazi mentality with his treatments and research, or whether he colluded with the Nazis and "accommodated" them to appear "useful" to the war effort as opined by one critic, ${ }^{67}$ is less clear.

Frankl and his former teacher Otto Pötzl resisted the Nazi "euthanasia" programs. Despite being a Nazi party member (Member Number 9,909,922 $2^{71}$ ) and supporter of sterilization of the mentally ill in 1938, ${ }^{72}$ Pötzl helped Frankl transfer Jewish brain tumor patients from Rothschild to the surgery unit at the 
University Clinic. He also helped Frankl resist Nazi euthanasia of the mentally ill. Frankl had already been transferring Jewish mentally ill patients to the Jewish senior home, where there were a few beds with protective bars and netting. Frankl bypassed Nazi laws prohibiting transfer of mentally ill patients to this type of home by diagnosing schizophrenics with "aphasia," and depressed patients with "fever delirium." These organic diseases were not subject to Nazi law. Subsequently, Pötzl also falsified diagnoses and transferred Jewish patients to the Jewish senior home. Frankl wrote, "[...] members of the National Socialist Party became victims of the euthanasia law while many Jewish patients in the same situation escaped it. Without Pötzl this would have been impossible." In an ironically tragic story, Frankl recounted how a mentally ill patient he was trying to transfer to the senior home could no longer be taken there because she had converted from Judaism, and thus had to be taken "via Steinhof to the gas chamber!" 66 Despite Frankl's and Pötzl's efforts, most of their patients were later deported and murdered in concentration camps. ${ }^{73,74}$

Frankl was lucky to be able to get one of the few American visas right before Pearl Harbor. He was on his way to the American consulate to pick up his visa, but decided to stay and care for his parents, since they did not have visas. Frankl delayed deportation by another year for himself and his family by offering some logotherapeutic advice to an agoraphobic Gestapo $\mathrm{SS}$ officer. But he and his family were eventually deported to the Theresienstadt ghetto in September $1942 .{ }^{66}$ Frankl worked as a general practitioner in a ghetto clinic until his neurologistpsychiatrist expertise became known, and he was asked to establish a special unit to help new prisoners overcome shock and grief. He later set up a suicide watch unit, and all suicidal ideations were reported to him. Frankl also headed the neurological clinic in block B IV, and gave lectures on various psychological and neurological topics. ${ }^{67} \mathrm{He}$ was deported from Theresienstadt to Auschwitz concentration camp in Poland in October $1944 .{ }^{66}$

At Auschwitz, Frankl barely made it past the selection line, as Dr. Josef Mengele had selected him for death, but he switched lines behind Mengele's back, because he saw his colleagues in the other line. Frankl survived selection, but lost the manuscript of "The Doctor and the Soul" (German, Ärztliche Seelsorge), which contained the essentials of his logotherapy, when he was forced to discard his overcoat (the manuscript was sewn into the coat). He later rewrote parts of it at the camps, on scraps of paper he collected (against camp rules). ${ }^{66}$ Frankl was prisoner 119,104 at Auschwitz for three to four days, before being transferred to Kaufering III, a Dachau sub-camp in Bavaria. He dug ditches there for five months, but realized he would not survive long in that work, thus requested transfer to the Türkheim sub-camp to be a doctor in a typhus ward, where he was transferred in March, 1945 until his liberation one month later. ${ }^{67}$

After the war, Frankl wrote that he could have developed logotherapy and finished his life's work earlier if he had emigrated to America before the war. But he believed he had his true test of maturation in the camps, and tested his theories "in vivo," confirming the survival value of "the will to meaning" and turning suffering into human triumph. Frankl argued that prisoners who had a meaning they wanted fulfilled (in his case, reconstructing his lost manuscript) were more likely to survive, which he later wrote about in "Man's Search for Meaning" (German, ...trotzdem ja zum Leben sagen: Ein Psychologe erlebt das Konzentrationslager, "...saying yes to life in spite of everything: A Psychologist Experiences the Concentration Camp). From 1946-1971, Frankl was head of the Neurology Department at the Vienna Policlinic Hospital, and later Lecturer at the University of Vienna. His "Man's Search for Meaning" was translated into 24 languages. ${ }^{66}$ In 1949, he obtained his PhD at the University of Vienna, ${ }^{67}$ in 1955 he became Professor of Neurology and Psychiatry at the University, and later also a visiting professor at Harvard University and other US universities. $^{75,76}$

Lucja Frey (1889-1943) - Born in Lwów, then part of the Austro-Hungarian Empire, followed by Poland in 1914, and currently is part of the Ukraine. ${ }^{77,78}$ (Figure 9) Frey's parents belonged to the liberal Lwów Jews who believed in education for girls, and she attended a Catholic elementary school. Her family was likely prosperous and assimilated, and they lived outside the traditional Jewish district, in a favored Polish neighborhood. ${ }^{77,78}$ As an example of assimilation, Frey later listed her native tongue as Polish, not Yiddish. ${ }^{78}$ She attended a Jewish high school, graduating in 1907 , then studied philosophy and mathematics at Lwów University. In 1917, there are conflicting reports about whether she began to study medicine in

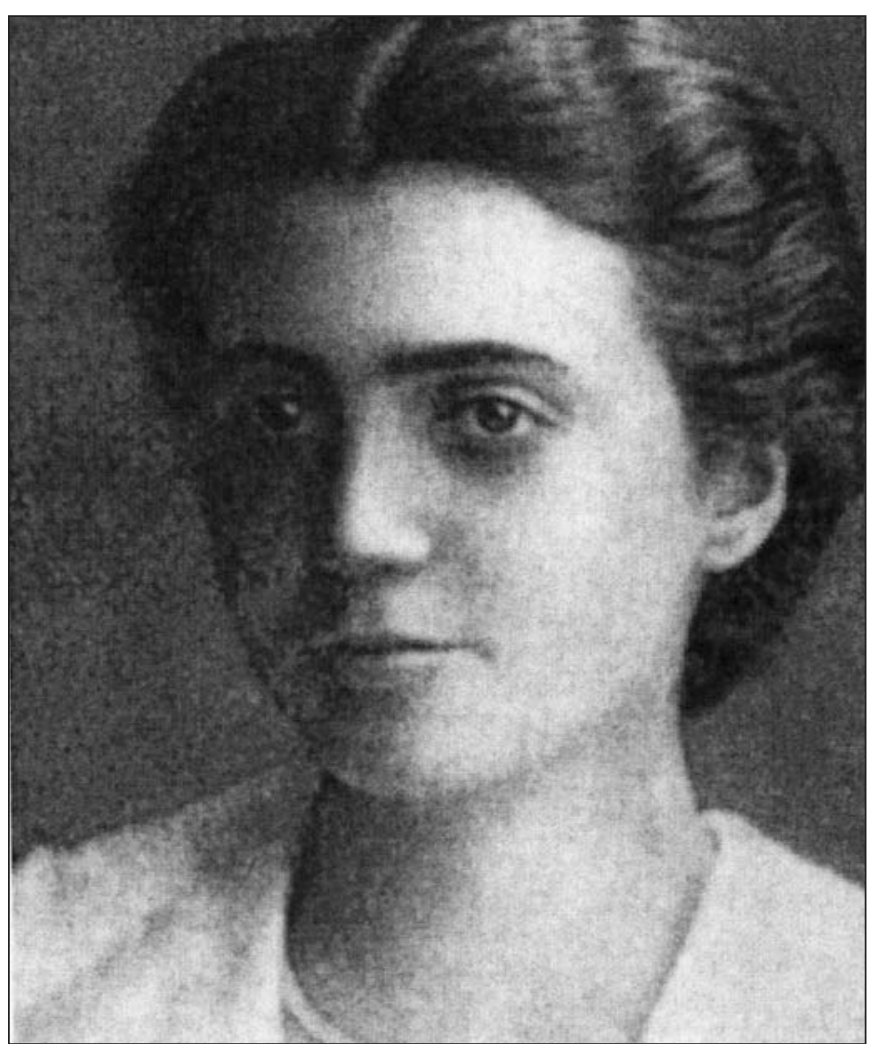

Figure 9: Lucja Frey, 1919. Photo first published in Herman E. Neurolodzy Polscy. Warsaw: Państwowy Zakład Wydawnictw Lekarskich; 1958. This photo is now in the public domain and is posted on www.commons.wikimedia.org. 
Lwów, or at Warsaw University. ${ }^{77,78}$ Professor Kazimierz Orzechowski, one of the most influential Polish neurologists of the time (Table 3) furthered Frey's professional development at the State Hospital of Lwów during the Polish-Ukrainian war. Frey then switched to the University of Warsaw to work as a junior assistant in the neurologic clinic where he was chair. ${ }^{77,78}$ She received her medical diploma in 1923, her examinations certifying her excellent knowledge of neurology and psychiatry. She worked as a senior assistant in the neurology clinic from 1923-28, and published papers on brain topography, the effects of vegetable poisons on spinal cord degeneration, anatomical changes in Charcot joints, multiple sclerosis, and hereditary neurologic diseases. ${ }^{77,78}$

Among her 43 publications are her 1923 papers $^{79,80}$ on auriculotemporal syndrome, later called Frey's syndrome. ${ }^{81,82}$ This syndrome is a late complication of parotid gland surgery, ${ }^{78-}$ 80 and Frey was the first to complete the anatomic-pathologic picture, describe the pathogenesis as involving the sympathetic and parasympathetic innervation, and suggest treatment. ${ }^{77,79,80}$ The syndrome, also known as gustatory sweating, results from anomalous renervation of the auriculo-temporal nerve, leading to unilateral or bilateral warmth, sweating, facial flushing, and altered tactile sensation during eating, smelling, tasting, or even thinking about food (as opposed to the expected salivation). The delay in the syndrome is likely from a post-surgical scar irritating and compressing the regenerating nerve. She hypothesized that ablation of the scar, surgical nerve decompression, or neurolysis with alcohol and partial nerve extirpation could treat the syndrome. ${ }^{77,79,80}$ Frey was described as "extraordinarily modest, quiet, and as hard-working as an ant...All her works were characterized by an exceptional accuracy, a seeking for a wide and versatile understanding of the problem under study as well as a deep knowledge of her subject."83

In 1928, Frey returned to Lwów and worked as a deputy senior consultant at the neurology outpatient clinic at the Jewish Hospital. By 1940, nearly half the population of Lwów were Jewish, especially after Jews from German-occupied Poland fled there to the Soviet-controlled town. Frey continued her work at the Jewish Hospital until the Germans conquered Lwów in 1941. One day after the German occupation, 7000 Jews were arrested, tortured, and murdered. In the first month of the Nazi occupation, 10\% of Lwów's Jews, or 17 000, died. Anti-Jewish laws were passed, and Jewish property was confiscated. Frey was forced to move into the Jewish ghetto, where rooms less than 10 square meters in size were made to accommodate ten people. Those who fled the ghetto were punished by death. ${ }^{78}$

At first physicians were considered "useful" and Frey worked in the second ghetto clinic. Forced labor, hunger, cold, arbitrary executions, and typhus decimated the ghetto population to 100 000. Deportations of Jews to the Belzec death camp began in 1942 with 15000 Jews, but the killing machinery was overburdened, so further deportations stopped temporarily. Lucja Frey received identity card no. 144 in April, 1942, one of 70000 cards issued to "necessary employees." That is the last piece of evidence that she was still alive. On August 20, 1942, because physicians were now considered "useless" and not skilled or technically qualified workers, the ghetto clinic's staff were murdered, along with their patients. At least 400 were shot. The Nazis had fixed the overload at Belzec and deportations had

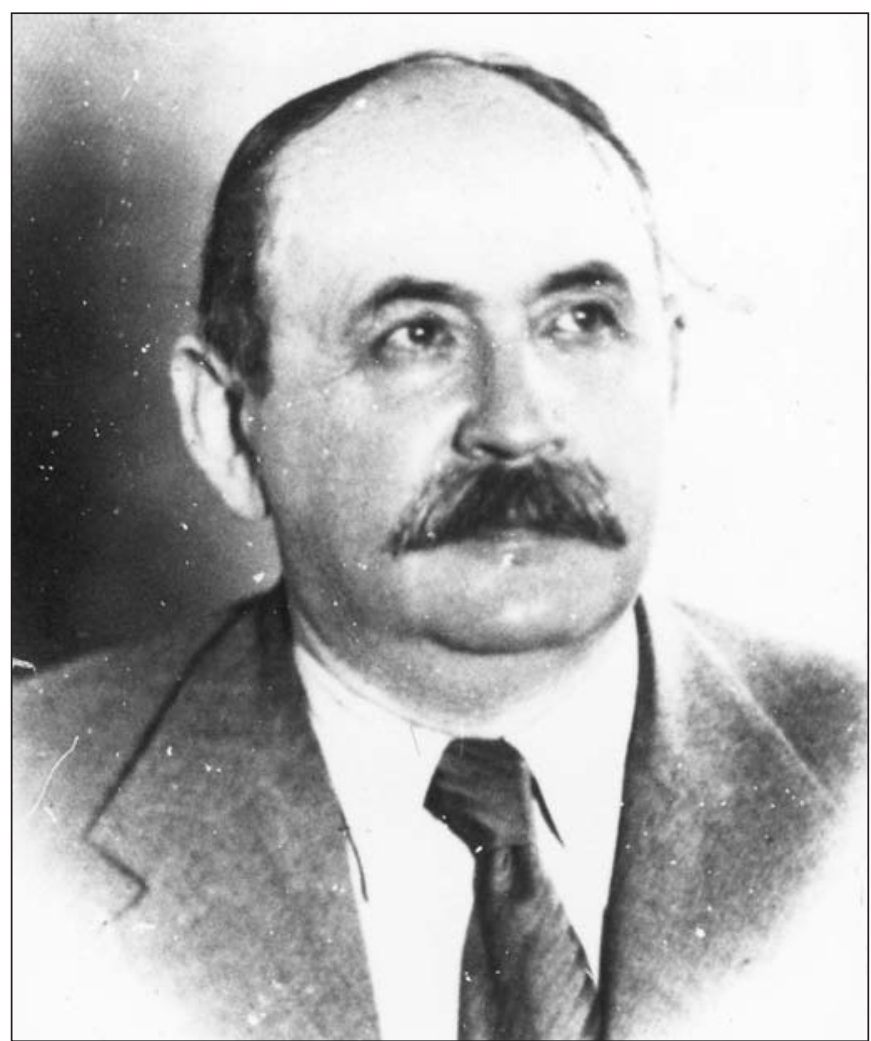

Figure 10: Wladyslaw Sterling, unknown year. Photo is in the Central Medical Library, Special Collection, catalogue number - sygn.2/1/5355, Warsaw, Poland.

begun again. Almost 50000 Jews were deported in August thus, even if Frey were not executed with the clinic staff, she was likely deported then. Only $70 \%$ of those deported actually made it to Belzec alive anyway, after several days journey in locked cattle railroad cars without food and water. The final liquidation of the ghetto occurred in June, 1943, and an attempt was made by the Nazis to remove all traces of mass murder, including digging up of graves, grinding skeletons in bone mills, and scattering ashes. Only 823 of the original 250000 Jews of metropolitan Lwów survived. There is no evidence that Frey was among them. ${ }^{78}$

Wladyslaw Sterling (1876-1943?) - Born in Warsaw into a scholarly family of physicians, art historians, and musicians (Figure 10). Sterling himself had broad interests outside of medicine, especially in music, writing, and poetry. ${ }^{84} \mathrm{He}$ published roughly 30 short poems from $1898-1900 .{ }^{85}$ Sterling was a lecturer at the University of Warsaw and was trained in neurology by Flatau. He was omnipresent at medical society meetings and he "participated in discussions offering interesting examples from his observations and his medical literature, encouraging others with his sharp voice to express [his] scholarly ideas." ${ }^{84}$ After Flatau's death in 1932, Sterling became head of the neurology clinic at the Jewish Hospital in Warsaw (na Czystem), where he had worked since 1905. ${ }^{85}$

Sterling published approximately 200 medical works, ${ }^{84}$ including about three previously undescribed neurological 
diseases. Together with Flatau he criticized Oppenheim's description of "dystonia musculorum deformans." Although Oppenheim and Georg Ziehen are credited eponymously with describing the disorder (Ziehen-Oppenheim Syndrome), it was Flatau and Sterling in 1911 who may have made the most astute observation of the syndrome.$^{86,87}$ They observed that progressive mobile spasms characterized the disorder, that it wasn't fixed and hypertonic, that not all patients became deformed, and that the term musculorum incorrectly implied that the involuntary movement was due to a muscle disorder. Additionally they noted that patients with the disorder may have unusually high intelligence, and highlighted the genetic nature of the disorder. ${ }^{86,87}$ Sterling also published on "epilepsia extrapyramidalis" (1924), later renamed striatal or subcortical epilepsy, on "dystrophia genitosclerodermica"(1916-26) and on "degeneration pyramidoextrapyramidalis" (1933-34, corticobasal degeneration). ${ }^{84}$ Sterling's reflex, described in 1926 , is similar to Rossolimo's finger sign, in which flexion of the fourth finger and the thumb is caused by a light stroke of the reflex hammer on the volar end of the two fingers. Sterling described the phenomenon with simultaneous stroking of all four fingers with the hammer instead. ${ }^{88}$

After the Nazi occupation of Poland in 1939, Sterling supported himself by a private neurology and psychiatry practice, after his government-supported position was eliminated ${ }^{85} \mathrm{He}$ may also have garnered financial support by treating a wealthy rabbi. ${ }^{89}$ But in November 1940 , the Nazis created the Warsaw ghetto, and Sterling was forced to move there, as all Jews were. In February 1941, a hospital was established in the ghetto, and Sterling worked at the neurology department there. The Nazis had given permission for a public health course to fight epidemics, and this course was a cover for an underground medical university which offered two years of courses, free of charge and financed by the Jewish community. ${ }^{85,90}$ One sources states that about 250 students were admitted, and 70 finished their studies, ${ }^{85}$ but another source states that 500 students enrolled and only 50 surviving students received certificates after the war. ${ }^{91}$ Along with neurologists Eufemiusz Herman and Anielę Gelbart, Sterling taught courses on neurology and child psychopathology, ${ }^{85,92}$ and he was also likely involved in clinical research. ${ }^{85}$ During 1942, a friend, Professor Henryk Makower, visited Sterling in his apartment in the ghetto, and wrote that he looked very thin, but still in good physicial condition. ${ }^{89}$ On July 22, 1942, lectures were cancelled, and the Nazis began to liquidate the ghetto. 300000 people were deported to Treblinka and other death camps within two months.$^{85,91}$ At this time, Sterling and his wife were allegedly smuggled out of the ghetto by Polish friends and hidden on the "Aryan" side in an apartment. ${ }^{89}$ They allegedly were baptized and obtained Polish papers, to remain as inconspicuous as possible..$^{85,90}$ While in hiding, and unable to practice neurology, he focused on his other love, and translated poetry. ${ }^{85}$ Ludwik Hirszfeld (brother of Sterling's wife Róża) later described the murder of his sister and her husband Sterling, ${ }^{93}$ either in $1943^{84,85,90}$ or in the spring of $1944 .{ }^{89}$ Apparently, neighbors started to talk about the danger they faced because of the two Jews hiding in the building. ${ }^{89}$ Sterling was generally somewhat anxious but, when two armed bandits appeared in the early morning in his bedroom, he was reportedly unusually calm. ${ }^{84} \mathrm{It}$ was written that he was smiling sardonically, his face a "garden of deadly irony," 89 but it is unknown who witnessed the situation. The bandits stole some of the Sterlings' property before murdering them both in bed, ${ }^{84,85,93}$ execution-style with a shot to the back of their heads. ${ }^{89}$ The neighbors called the German police, but the police merely shared the stolen goods with the bandits and then set them free, since the bandits were actually Nazi Gestapo employees. ${ }^{93}$ A day before the end of the war, the Sterlings' murder was investigated by a tribunal of the Polish underground resistance movement (Armia Krajowa, Home Army), ${ }^{93,94}$ but it is unclear whether any punishment ever came to the bandits. The Sterlings' murder was likely a Nazi act aimed to eliminate Polish Jewish elite before the end of the war. ${ }^{89,93}$

\section{DiscuSSION}

The stories of the seven Jewish neuroscience victims we detailed above are exemplary of the persecution of physicians in the Nazi era. These neuroscientists were trapped in the vortex of racial hatred and anti-Semitism that were the tenets of Nazism. Though anti-Semitism existed prior to the Nazi era in both Germany and Austria, and also in Poland, the intensity of racially infused legislation intended to strip professional then personal rights, prior to technologically proficient and efficient mass murder, had never been seen before in the history of mankind. Jewish neuroscientists, like all Jewish doctors, were the only ones capable of prolonging Jewish neurologic patients' lives, thus they were likely targeted by Nazi brutality more intensely than other Jews.

In Germany, Pick, Simons, and Weichbrodt all served as military physicians in WWI, and Pick was a decorated veteran. The military records of these three neuroscientists did not prevent their dismissal as part of the 1933 Nazi Reconstitution Law; Hindenburg exemptions only applied to those veterans who had served on the front in the Great War. Pick's war record, however, may have prevented his deportation to Auschwitz death camp while he was at the Theresienstadt ghetto. Holders of the Iron Cross, First Class were exempt from deportation to Auschwitz as of March 5, 1942. ${ }^{95}$ Pick died of pneumonia, however, in 1944 while imprisoned in the ghetto. The fact that Pick and Weichbrodt were reform, non-religious assimilated Jews also did not save them from persecution, as Nazi antiSemitism was racially, not religiously, motivated. An international scientific reputation did not prevent Pick's eventual deportation to Theresienstadt, nor did his relationship with his non-Jewish fiancée who he was forbidden to marry by Nazi law. Pick and Weichbrodt, like Austrian neuroscientist Frankl, refused opportunities to emigrate abroad. Pick, feeling highly assimilated and loyal to his German Fatherland, didn't feel that the Nazi Rassenhygiene (racial hygiene) policies would ever lead to his imprisonment and death, and refused positions in Shanghai and Chicago. Frankl was probably less deluded, but decided not to abandon his parents. Many Austro-German Jewish doctors failed to realize how different Hitler's brand of anti-Semitism was from prior Jew hatred. Indeed, Hitler was looking to impose an organized, systematic anti-Semitism more malignant and catastrophic than ever before. He wrote in his infamous book Mein Kampf (My Struggle) regarding the less virile anti-Semitism of the past, stating ominously that "the Jew 
is so accustomed to this type of anti-Semitism [unofficial and unorganized] that he would have missed its disappearance more than its presence inconvenienced him."96

The majority of Jewish doctors were able to emigrate from Nazi Germany, despite the fact that most countries had tightened immigration policies. Beside a false sense of security from a distinguished military record during WWI (Hindenburg Jews), and the sense of assimilation of German and Austrian Jews, as well as the delusion about the difference between Nazi antiSemitism and prior anti-Semitism, there were other practical reasons why 2000 Jewish doctors did not emigrate. The first and most important hurdle was a financial one, which most Jewish doctors were able to overcome. ${ }^{7}$ Family ties in foreign countries had to be taken into account, as well as language abilities (at that time Latin and French were more common as second languages than English). Indeed, few emigrated early in the Nazi regime; those who did were either prominent elder scientists with an established international network, or young physicians who had nothing to lose in Germany. ${ }^{97}$ Doctors over 60 years old most likely stayed behind, and roughly $2 / 3$ of physicians who emigrated were under 45 years. $^{7}$ Yet from our Table 1 , only $6 / 28$ $(21 \%)$ of Berlin neuroscience victims were under 45 years at the time of the Nazi takeover in Germany in 1933, and 7/28 (25\%) were 60 years or older (including Pick). Simons and Weichbrodt fall in between, thus their decision does not fit the age trend. Similarly to Berlin neuroscientist victims, Austrian/Czechs do not seem to follow the age trend of physicians overall with respect to emigration. From Table 2, only 3/11 Austrian/Czech victims (27\%) were under 45 years (including Frankl), and 5/11 (45\%, including Spitzer) were over 60 years at the time of the Nazi annexation of Austria in 1938.

Visas were needed for foreign emigration, and these were increasingly difficult to obtain in the 1930s for Jewish emigrant hopefuls. This timetable of difficulty was unfortunately inversely related to the need most German and Austrian Jews felt to emigrate. Indeed early in the Nazi regime, many Jewish doctors were still extremely busy, a Nazi coup in Vienna failed, and the 1936 Berlin Olympics produced a relative distraction; thus there was a false sense of security. ${ }^{7}$ Beginning in 1937 , the number of German Jewish emigrants escalated from 23000 , to 40000 in 1938, and to 78000 in 1939, especially after Kristallnacht in November 1938 (and full delicensure for Jewish physicians after September 1938). ${ }^{7,97}$ Unless certain criteria were met for a foreign visa ${ }^{\mathrm{h}}$ most were put on long quota lists, which became longer by the end of the 1930s. ${ }^{7}$ In addition, the Nazis hoped to pilfer Jewish wealth from desperate emigrants. The 1934 Reich Flight Tax (German, Reichsfluchsteuer) "punished" Jews for fleeing by charging them with one-quarter of their assets to be allowed to leave (if their annual post-1931 income was greater than 20000 marks, or they possessed more than 50000 marks in assets). By 1938-39, the height of Jewish desperation to emigrate, the Nazis claimed up to $96 \%$ of Jewish assets prior to departure, and the Nazis collected about 900 million marks total by 1940 from fleeing Jews. ${ }^{7}$
Other neighbouring European countries such as Holland or France or Yugoslavia were transient safehavens for emigrant neuroscientists, but were not long term options. ${ }^{7}$ The US was the most common destination for German immigrants, ${ }^{7}$ but the quota for about 25000 immigrants was not met once until 1939. ${ }^{7,97}$ Indeed, the 1924 US quota system was meant to keep out "Bolshevik Wops, Dagoes, Kikes, and Hunkies" from entering the system, and after the Great Depression began in 1929, federal and state legislators as well as industry leaders advocated further racist and anti-Semitic restrictions from Jewish immigration to the US. New York, Massachusetts, New Jersey, Connecticut, Maryland, and Illinois were the most liberal for Jewish immigrants from Austria or Germany. Pick refused an offer to emigrate and become a professor in Chicago. Frankl was fortunate enough to be selected from the Austrian quota list and was granted a visa for US immigration but refused it. Britain fell behind France in taking in Jewish emigrants, possibly because of the British desire for appeasement of the Nazis but, more likely, because of anti-Semitism in the setting of the crippling Great Depression. Preferential treatment toward "distinguished" German-Jewish physicians to emigrate to Britain did occur, due to the British penchant for scholarship, and some worldrenowned scholars were able to emigrate there. Weichbrodt received an offer to emigrate to the UK but refused for unknown reasons. Simons attempted to emigrate to the UK but failed. Also, the internationally administered Free Zone of Shanghai, without any visa requirement, was a destination for some emigrant doctors, who were able to set up medical practices there until they could emigrate elsewhere, ${ }^{7}$ though Pick refused a professorship there.

Another deterrent from emigrating was the dissemination of reports from German-Jewish agencies regarding psychological adjustment problems, as well as restrictive quotas and poor working conditions in many specialties and difficulty obtaining practice licenses. ${ }^{7}$ Those physicians who entered the US before 1936 encountered the least difficulties (in New York only a language exam was required to start private practice), but then state medical licensing boards tightened restrictions. Namely, US citizenship became a requirement for a license to practice medicine, and one had to be a permanent resident for five years to obtain citizenship. Even famed Austrian neurologist and neuropathologist Otto Marburg (1874-1948), who described the Marburg variant of multiple sclerosis, author of at least ten books and over 200 articles, had to go through an ordeal with the New York State Licensing board to try to get his Austrian license endorsed without taking an examination (as he had reached a position of "conceded eminence"). His attempt failed but he was granted a new license instead. ${ }^{98}$ In Britain, no emigrant physician was allowed to practice without years of repeated study and a medical examination. ${ }^{7}$ Neuroscientists Michael Balint, Friedrich H. Lewy, and Robert Wartenberg were forced to emigrate and their careers flourished in the US, ${ }^{99}$ and Heidelberg neuropsychiatrists Willy Mayer-Gross ${ }^{27}$ and Karl Stern ${ }^{26}$ found success in Great Britain. But many who left never regained the

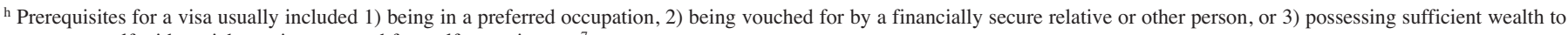
support oneself without job earnings or need for welfare assistance. ${ }^{7}$ 
momentum of their research careers, due to circumstances and limited opportunities in their new homes. ${ }^{99}$ Sadly, many emigrant physicians were forced to wait many years to reestablish themselves professionally, and had to take menial unprofessional jobs in the meantime to support themselves. ${ }^{7}$

The fates of Lucja Frey and Wladyslaw Sterling in occupied Poland and Ukraine are reflective of the Nazi policy toward Jews in the occupied Eastern territories. Immediately after occupation, the Nazis carried out pogroms in areas where Jews were concentrated. They acted without restraint in their murder, since no neutral observers were present. This was substantially different than the methods employed in Western and Central Europe. The chances of survival in Nazi occupied countries were nil even if one observed all Nazi ordinances - this was not what was expected if one merely based expectations on the stepwise marginalization of Jews in Germany and Austria. Also, countries like Poland and the Soviet Union, which had strong local resistance against the Nazis, seemed to suffer the most retaliatory slaughter of the Jews from those countries. Nazi propaganda against Jews began in earnest immediately after occupation and the confused and humiliated local population was impressed upon that the Jew was at fault for their invasion and oppression, thus Jews became a convenient scapegoat. ${ }^{95}$ In addition, as mentioned previously, the Nazis had more hatred of Eastern European Jewry than the Jews of Western Europe. ${ }^{7}$ The treacherous and deceitful execution of Sterling and his wife, who had received help from non-Jewish friends in escaping the Warsaw ghetto during its liquidation, is exemplary of the worsened persecution in occupied countries with strong local resistance, and of Nazi attempts to eliminate potential would-be healers of the hated Eastern Jewry.

\section{Conclusions}

Germany was the world's leading nation in the field of neuroscience and medicine until the rise of the Nazi regime. By 1933, six Nobel prizes in physiology or medicine had been awarded to German scientists compared to only one to an American scientist. ${ }^{100}$ The emigration of a large number of its best scientists to the US caused Germany to lose its leading scientific position to the US. ${ }^{97}$ Those neuroscientists who did not emigrate became entangled in the Nazi attempt to wipe what they viewed as the Jewish "race" off the planet. These neuroscientists did not emigrate from Nazi Germany for a number of reasons. They were deluded as to the radical nature of Hitler's brand of anti-Semitism, as were most of the Jewish victims of the Holocaust, and most people of the world in general. Specifically, in the case of Pick, Simons, and Weichbrodt, they believed that their war record would save them from persecution. That hope was shattered when they all lost their positions at German universities in 1933, and then were progressively stripped of their professional rights to privately practice or to practice medicine at all. This was accompanied by loss of personal rights such as use of automobiles, loss of personal wealth, and demeaning Nazi tactics such as mandatory assignment of "Jewish" middle names and requirements to wear a Jewish Star of David on all outer clothing to prevent assimilated Jews from maintaining anonymity. Despite prohibitive expenses and difficulties in obtaining visas to emigrate, as well as finding positions in foreign countries, Pick and Weichbrodt could have emigrated to the USA or the UK, but did not. In Pick's case, he was fiercely loyal to what he perceived as his German fatherland and possibly hoped the situation would turn around after 1933. For Weichbrodt, his reasons for refusing the UK position are less clear. The Austrian Frankl was able to obtain a visa to the US but did not want to abandon his family. Frankl's actions during the war demonstrate that we cannot paint physicians in the Nazi era in black and white, ${ }^{6,27}$ in that he conducted questionably ethical and irresponsible neurosurgical research on suicidal Jewish patients and participated in a Nazisponsored psychology group. At best, Frankl simply acted in parallel with Nazi mentality in regard to suicide prevention and his neurosurgical research, idealistically and naively to save lives and publish his research, while brazenly resisting Nazi euthanasia and becoming a victim himself.

The ethical vacuum that made the Holocaust possible ${ }^{29}$ will hopefully not be allowed to take place in the future. Remembering the victims of neuroscience during the Nazi era, and discussing their circumstances, is just a start and more research must be done to document the atrocities and hopefully have some impact on neuroscience educational curricula. Discrimination against Jews and other minorities in medicine was not restricted to Germany, and was rampant in U.S. medical education also. ${ }^{101}$ For the present generation of Jewish physicians, who are not impeded or persecuted openly at least, the hope remains that anti-Semitism will not re-emerge as it has so many times in the past despite periods of relative inactivity. This hope must remain strong, despite reports from Europe that are concerning and highlight the need for continued vigilance. ${ }^{99}$ For the sake of us all, doctors, as ambassadors of humanity, must uphold the tenets of tolerance and acceptance, to set an example to the world of how history cannot repeat itself.

\section{ACKNOWLEDGMENTS}

The authors thank Anna Gasienica-Byrcyn, Ph.D. (Lecturer in Polish Language \& Literature, University of Illinois at Chicago), Lauren and Lucyna Mohan (Chicago), Wieslawa Nosowicz and Kinga Mateja (UIC Medical Center Translation Services), Danuta Goralska-Olsen (Copenhagen Muscle Research Center, Copenhagen), Grazyna Herczynska (History of Polish Psychiatry Unit, Institute of Psychiatry and Neurology, Warsaw) for assistance in translating and supplying documents and photos related to Wladyslaw Sterling; Dr. Elisabeth Klamper (Archivarin, Dokumentationsarchiv des österreichischen Widerstandes, Vienna, Austria) for providing the picture of Viktor Frankl and staff; Professor Bernd Holdorff (Department of Neurology, Schlossparkklinik, Berlin) for providing the Arthur Simons picture; and Barbara Bieringer (Archive, University of Vienna) for supplying the picture of Alexander Spitzer.

\section{REFERENCES}

1. Zeidman LA. Neuroscience in Nazi Europe Part I: eugenics, human experimentation, and mass murder. Can J Neurol Sci. 2011;38 (5):696-703.

2. Cohen MM Jr. Genetic drift: overview of German, Nazi, and Holocaust medicine. Am J Med Genet A. 2010;152A(3): 687-707.

3. Hughes JT. Neuropathology in Germany during World War II: Julius Hallervorden (1882-1965) and the Nazi programme of 'euthanasia'. J Med Biogr. 2007;15(2):116-22. 
4. Burleigh M. 'Wheels must roll for victory!' Children's 'euthanasia' and 'Action T4.' In: Death and deliverance: 'Euthanasia' in Germany c. 1900-1945. Cambridge, UK: Cambridge University Press; 1994. p. 93-129.

5. Shevell MI. Neurosciences in the Third Reich: from Ivory Tower to death camps. Can J Neurol Sci. 1999;26(2):132-8.

6. Zeidman LA. Neuroscience in Nazi Europe Part II: resistance against the Third Reich. Can J Neurol Sci. 2011;38(6):826-38.

7. Kater MH. The persecution of Jewish physicians. In: Doctors under Hitler. Chapel Hill: University of North Carolina Press; 1989. p. 177-221.

8. Freedman S. Antisemitism and the history of Myasthenia Gravis. Isr Med Assoc J. 2010;12:195-8

9. Efron JM. Before the storm. Jewish doctors in the Kaiserreich and the Weimar Republic. In: Medicine and the German Jews. New Haven, CT: Yale University Press; 2001. p. 234-9.

10. Oppenheim H. Die Myasthenische Paralyse (Bulbärparalyse ohne anatomischen Befund). Berlin: JHH Karger; 1901.

11. Herlitz G, Kirschner B, editors. Jüdisches Lexikon, volume 4. Berlin: Jüdischer Verlag; 1930. p. 583-4.

12. Holdorff B. Founding years of clinical neurology in Berlin until 1933. J Hist Neurosci. 2004;13(3):223-38

13. Peiffer J. Hirnforschung in Deutschland 1849 bis 1974: Briefe zur Entwicklung von Psychiatrie und Neurowissenschaften sowie zum Einfluss des politischen Umfeldes auf Wissenschaftler. Berlin, Heidelberg, New York: Springer Verlag; 2004.

14. Wilhelm Erb to Adolph von Strümpell, 8 February 1894. In: Peiffer J. Hirnforschung in Deutschland 1849 bis 1974: Briefe zur Entwicklung von Psychiatrie und Neurowissenschaften sowie zum Einfluss des politischen Umfeldes auf Wissenschaftler. Berlin, Heidelberg, New York: Springer Verlag; 2004. Document 173

15. Wilhelm Erb to Adolph von Strümpell, 22 December 1912. In: Peiffer J. Hirnforschung in Deutschland 1849 bis 1974: Briefe zur Entwicklung von Psychiatrie und Neurowissenschaften sowie zum Einfluss des politischen Umfeldes auf Wissenschaftler. Berlin, Heidelberg, New York: Springer Verlag; 2004. Document 757.

16. Wilhelm Erb to Adolph von Strümpell, 23 January 1920. In: Peiffer J. Hirnforschung in Deutschland 1849 bis 1974: Briefe zur Entwicklung von Psychiatrie und Neurowissenschaften sowie zum Einfluss des politischen Umfeldes auf Wissenschaftler. Berlin, Heidelberg, New York: Springer Verlag; 2004. Document 993.

17. Julius Wagner-Jauregg to Max Nonne, 13 June 1918. In: Peiffer J. Hirnforschung in Deutschland 1849 bis 1974: Briefe zur Entwicklung von Psychiatrie und Neurowissenschaften sowie zum Einfluss des politischen Umfeldes auf Wissenschaftler. Berlin, Heidelberg, New York: Springer Verlag; 2004. Document 962.

18. Friedrich Schultze to Adolph von Strümpell, 6 February 1913. In: Peiffer J. Hirnforschung in Deutschland 1849 bis 1974: Briefe zur Entwicklung von Psychiatrie und Neurowissenschaften sowie zum Einfluss des politischen Umfeldes auf Wissenschaftler. Berlin, Heidelberg, New York: Springer Verlag; 2004. Document 766

19. Hugo Spatz to Julius Hallervorden, 20 May 1930. In: Peiffer J. Hirnforschung in Deutschland 1849 bis 1974: Briefe zur Entwicklung von Psychiatrie und Neurowissenschaften sowie zum Einfluss des politischen Umfeldes auf Wissenschaftler. Berlin, Heidelberg, New York: Springer Verlag; 2004. Document 1153.

20. Max Nonne to Friedrich Schultze, 12 February 1934, "On the topic of rejection of the work (dissertation)." In: Peiffer J. Hirnforschung in Deutschland 1849 bis 1974: Briefe zur Entwicklung von Psychiatrie und Neurowissenschaften sowie zum Einfluss des politischen Umfeldes auf Wissenschaftler. Berlin, Heidelberg, New York: Springer Verlag; 2004. Document 1404

21. Schoell-Glass C. Aby Warbung und der Antisemitismus. Frankfurt/ Main: S. Fischer; 1998
22. Schmiedebach HP. Jüdische Ärzte in Berlin. Wissenschaft und ärztliche Praxis im Spannungsfeld zwischen Emanzipation und Antisemitismus (I. Teil). Berliner Artzeblatt 2002;116:14-18.

23. Schagen U. Wer wurde vertrieben? Wie wenig wissen wir? Die Vertreibungen aus der Berliner Medizinischen Fakultät 1933. Ein Überblick. In: Schleiermacher S, Schagen U, editors. Die Charité im Dritten Reich. Paderborn: Ferdinand Schöningh; 2008

24. Hartshorne EY. The German Universities and National Socialism. London: Harvard University Press; 1937.

25. Hubenstorf M, Walther PT. Politische Bedingungen und allgemeine Veränderungen des Berliner Wissenschaftsbetriebes 1925-1950. In: Fischer W, Hierholzer K, Hubenstorf M, Walther PT, Winau $\mathrm{R}$, eds. Exodus von Wissenschaften aus Berlin. Berlin, New York: de Gruyter; 1994. p. 33.

26. Strauss HA, Buddensieg T, Düwell K, editors. Emigration: Deutsche Wissenschaftler nach 1933, Entlassung und Vertreibung. Berlin: Technische Universität Berlin; 1987.

27. Kater MH. Medical faculties in crisis. In: Doctors under Hitler. Chapel Hill: University of North Carolina Press; 1989. p. 111-49.

28. United States Holocaust Memorial Museum. [United States Holocaust Memorial Museum, Kristallnacht page on the Internet]. Washington, DC: United States Holocaust Memorial Museum; c2012 [update 2012; cited 2012 May 2]. Available from: http://www.ushmm.org/museum/exhibit/online/kristall nacht/frame.htm

29. Haag J. The University of Vienna and the Anschluss. In: Burton JK, White CW, editors. Essays in European history. Selected from the Annual Meetings of the Southern Historical Association, 1988-1989, Volume II. Lanham, Maryland: University Press of America; 1996. p. 29-44.

30. Koestler A. The case of the midwife toad. New York: Random House; 1971. p. 121.

31. Hubenstorf M. Österreichischer Ärzte-Emigration. In: Stadler F, editor, Vertriebene Vernunft. Emigration und Exil Österreichischer Wissenschaft 1930-1940. Wien-München: Jugend und Volk; 1987. p. 360-95.

32. Karady V. Gewalterfahrung und Utopie. Juden in der europäischen Moderne. Frankfurt/Main: S. Fischer; 1999. p. 135.

33. Mahler R. Jews in public service and the liberal professions in Poland, 1918-1939. Jewish Soc Stud. 1944;6:291-350.

34. Jolly F. Uber Myasthenia gravis pseudoparalytica. Berlin Klin Wochenschr. 1895;32:1-7.

35. Simmer HH: Der Berliner Pathologe Ludwig Pick (1868-1944). Husum: Matthiesen Verlag; 2000.

36. Firkin BG, Whitworth JA. Dictionary of medical eponyms. Parthenon, Carnforth, 1987.

37. Schwoch R, editor. Berliner jüdische Kassenärzte und ihr Schicksal im Nationalsozialismus: Ein Gedenkbuch. Berlin: Hentrich \& Hentrich; 2009.

38. Gottwaldt A, Schulle D. Die "Judendeportationen" aus dem Deutschen Reich 1941-1945. Wiesbaden: Marix Verlag; 2005.

39. Bundesarchiv (Hrsg). Gedenkbuch „Opfer der Verfolgung der Juden unter der nationalsozialistischen Gewaltherrschaft in Deutschland 1933-1945,“ 2, wesentlich erweiterte Auflage. Berlin: Bundesarchiv; 2006.

40. Holdorff B. Arthur Simons über tonische Halsreflexe beim Hemiplegiker. Aus den Jahren 1916-1919. Nervenarzt. 2012;83: 512-20.

41. Simons A. Eine seltene Trophoneurose (Lipodystrophia progressiva“). Zeitschrift für die gesamte Neurologie und Psychiatrie. 1911;5:29-38.

42. Greene AK. Lluis Barraquer-Roviralta (1855-1928): Spanish neurologist described progressive lipodystrophy. Plastic Reconstructive Surg. 2001;107(1):158-62.

43. Barraquer L. Histoire clinique d'un cas d'atrophie du tissue celluloadipeux. Neurol Centralblatt. 1907;26:1072.

44. Simons A. Kopfhaltung und Muskeltonus. Ref Zentralbl Neurol. 1920;39:132-7.

45. Simons A. Kopfhaltung und Muskeltonus. Z Ges Neurol Psychiatr. 1923;80:499-549. 
46. Simons A. Kopfhaltung und Muskeltonus, (Weitere klinische Beobachtungen). Zentralbl Neurol. 1925;40:372-5.

47. Schäfer K. Verfolgung einer Spur (Raphael Weichbrodt). Frankfurt am Main: Fritz Bauer Institut; 1998.

48. Weichbrodt R. Experimentelle Untersuchungen zur Salvarsantherapie der Paralyse. Deutsch Med Wochenschr. 1921; 47:69-71.

49. Nathan E, Weichbrodt R. Untersuchungen über die Wassemannsche Reaktion bei Paralytikern. Archiv Dermatol Syph. 1921;135: 308-18.

50. Bieling $\mathrm{R}$, Weichbrodt $\mathrm{R}$. Untersuchung über die Austauschbeziehungen zwischen Blut und Liquor cerebrospinalis. Archiv Psych Nervenkr. 1922;65:552-71.

51. Weichbrodt R. Zur Dementia praecox im Kindesalter. Archiv Psych Nervenkr. 1918;59:101-9.

52. Anonymous. Ein lehrreiches Dozenten-Verzeichnis. Der Weltkampf, vol. 119, Munich, November 1933.

53. Weichbrodt R. Der Selbstmord. Basel, Switzerland: Karger; 1937.

54. Weichbrodt death certificate, civil registry office, Arolsen.

55. Lev M, Vass A. Alexander Spitzer - A biographic note. In: Spitzer A. The architecture of normal and malformed hearts: a phylogenetic theory of their development. [Translated Reprint from the original German version] Springfield: Charles C. Thomas Publisher; 1951. p. xi-xiv.

56. Hubenstorf M. Tote und/oder lebendige Wissenschaft: Die intellektuellen Netwerke der NS-Patientenmordaktion in Österreich. In: Gabriel E, Neugebeauer W, editors. Von der Zwanssterilizierung zur Ermordung: Zur Geschichte der NSEuthanasie in Wien. Wien: Böhlau Verlag; 2002. p. 237-420.

57. Spitzer A. Ein Fall von Tumor am Boden der Rautengrube. Beitrag zur Kenntnis des hinteren Laengsbuendels. Arbeiten aus dem Institut fuer Anatomie und Physiologie des Centralnervensystems an der Wiener Universitaet. 1899;6:1-58.

58. Spitzer A. Migräne. Jena: Fischer Verlag; 1901.

59. Spitzer A, Karplus JP. Zur Kenntnis der abnormen Buendel im menschlichen Hirnstamm. Arbeiten aus dem Institut fuer Anatomie und Physiologie des Centralnervensystems an der Wiener Universitaet. 1904;11:29-54.

60. Über die Kreuznung der centralen Nervenbahnen und ihre Beziehungen zur Phylogenese des Wirbeltierkoerpers. Leipzig und Wien: Franz Denticke; 1910.

61. Spitzer A. Anatomie und Physiologie der zentralen Bahnen des Vestibularis. Arbeiten aus dem neurologischen Institut an der Wiener Universitaet. 1924;25 (2 and 3): 423-70.

62. Spitzer A. Über die Function der Bogengaenge des Ohrlabyrinthes. Monatschrift fuer Ohrenheiljunde und Laryngo-und Rhinologie. 1925;59:1-46.

63. Gould GM. The history and etiology of "Migraine." JAMA. 1904; XLII(4):239-44.

64. Strous RD, Edelman MC. Eponyms and the Nazi era: time to remember and time for change. Isr Med Assoc J. 2007;9(3): 207-14.

65. Theresienstädter Gedenkbuch. Österreichische Jüdinnen und Juden in Theresienstadt $1942-1945$. Prague: 2005. p. 318

66. Frankl VE. Viktor Frankl recollections, an autobiography. New York, Plenum Press; 1997.

67. Pytell T. The missing pieces of the puzzle: a reflection on the odd career of Viktor Frankl. J Contemporary History. 2000;35(2): 281-306.

68. Frankl VE. Pervitin Intrazisternal. Ars Medici. 1942;1:58-60.

69. Viktor Frankl lecture, United States International University, 20 February 1972. As referenced in: Pytell T. The Missing Pieces of the Puzzle: A Reflection on the Odd Career of Viktor Frankl. Journal of Contemporary History. 2000;35(2):281-306.

70. Kwiet K. The Ultimate Refuge: Suicide in the Jewish Community under the Nazis. Yearbook Leo Baeck Institute. 1984;29:135-67.

71. Bundesarchiv Berlin, Unterlagen des ehemaligen BDC, Otto Pötzl.

72. Hubenstorf M. Medizinische Fakultät 1938-1945. In: Willfärige Wissenschaft: Die Universität Wien 1938-1945. Wien: Verlag für Gesellschaftskritik; 1989. p. 275, footnote 92.

73. Strous R. Extermination of the Jewish Mentally-Ill during the Nazi Era - The "Doubly Cursed." Isr J Psychiatry Relat Sci. 2008;45 (4):247-56
74. Neugebauer W. Juden als Opfer der NS-Euthanasie in Wien 19401945. In: Gabriel E, Neugebauer W, editors. Von der Zwangssterilisierung zur Ermordung. Wien: Bohlau Verlag; 2002. p. 99-112.

75. Viktor Frankl Institute [The Official Website of the Viktor Frankl Institute, Vienna page on the Internet]. Vienna: Viktor Frankl Institut; c2012 [update 2012; cited 2012 April 17]. Available from: http://www.viktorfrankl.org/e/lifeandwork.html.

76. Redsand A. A time to live. In: Viktor Frankl: a life worth living. New York: Clarion Books; 2006. p. 97-112.

77. Maciejewska I, Dziewiatkowski J, Spodnik E. Lucja Frey: a pioneering physician in tragic times. Clin Anat. 2007;20:588-90.

78. Moltrecht M, Michel O. The woman behind Frey's Syndrome: the tragic life of Lucja Frey. Laryngoscope. 2004;114:2205-9

79. Frey L. Przypadek zespolu nerwu usznoskroniowego. Pol Gaz Lek. 1923;41:708-10

80. Frey L. Le syndrome du nerf auriculo-temporal. Rev Neurol. 1923; II:97-104.

81. Higier S. Das auriculo-temporale Syndrom und seine Pathogenese. Z Ges Neur Psych. 1926;106:114-19.

82. Bassoe PN. The auriculotemporal syndrome and other vasomotor disturbances about the head. Med North Am. 1932;16:405-12.

83. Herman E. Wspomnienia posmiertne. Neurol Pol 1950;XXIV:27-8.

84. Herman E. Neurolodzy Polscy. Warsaw: Państwowy Zakład Wydawnictw Lekarskich; 1958.

85. Herczyńska G. Wladyslaw Sterling: 1877-1943. Postępy Psychiatrii i Neurologii. 2005;14(1):3-7.

86. Eldridge R. Flatau E, Sterling W. Torsion Spasm in Jewish Children, and the early history of human genetics. In: Eldridge R, Fahn S, editors. Advances in Neurology, Vol. 14. New York: Raven Press; 1976. p. 105-14.

87. Flatau E, Sterling W. Progressive Torsionspasms bei Kindern. Z Gesamte Neurol Psychiatr. 1911;7:586-612.

88. Sterling W. Les phénomènes des doigts analogues aux signes de Babinski et de Rossolimo. Rev Neurol. 1926;2:82-8.

89. Marianowicz A. Professor Sterling. In: Życie Surowo Wzbronione. Warszawa: Czytelnik; 1995. p. 259-65.

90. Polski Słownik Biograficzny, Vol. 43 (3), Steinhagen Henryk Sternfeld Ary. Warszawa-Krakówa: IHPAN; 2005. p. 445-6.

91. Engelking B, Leociak J. Medical Education. In: The Warsaw Ghetto: a guide to the perished city. New Haven and London: Yale University Press; 2009. p. 248-55.

92. Zablotniak R. Wydzial Lekarski W Getcie Warszawskim. Biuletyn Zydowskiego Instytutu Historycznego (BZIH). 1970;74:81-5

93. Hirszfeld L. Historia jednego życia [The Story of One Life]. Warszawa: Czytelnik; 1946.

94. Personal Communication, Grażyna Herczyńska, History of Polish Psychiatry Unit, Institute of Psychiatry and Neurology, Warsaw, Poland. 16 February 2012.

95. Lederer Z. Ghetto Theresienstadt. New York: Howard Fertig; 1983.

96. Pauley BF. Reflections on Austrian Anti-Semitism. In: Burton JK, White CW, editors. Essays in European History. Selected from the Annual Meetings of the Southern Historical Association, 1988-1989, Volume II. Lanham, Maryland: University Press of America; 1996. p. 137-49.

97. Walther PT. Entlassungen und Exodus. Personalepolitik an der Medizinischen Fakultät 1933. In: Schleiermacher S, Schagen U, editors. Die Charité im Dritten Reich. Ferdinand Schöningh, Paderborn, 2008

98. Triarhou LC. Professor Otto Marburg, universal neurologist and the 'dean of teachers.' Wiener Klinische Wochenschrift. 2008;120: 622-30.

99. Strous RD. Antisemitism and the history of medicine: the challenge then and now. Isr Med Assoc J. 2010;12:229-30.

100. Vossen K. Willfährige Wissenschaft: Die Medizinische Fakultät der Berliner Universitet und der Nationalsozialismus. In: Schleiermacher S, Schagen U, editors. Die Charité im Dritten Reich. Paderborn: Ferdinand Schöningh; 2008.

101. Halperin EC. The Jewish problem in U.S. medical education, 19201955. J Hist Med Allied Sci. 2001;56:140-67. 